\title{
Review
}

\section{COVID-19: A Comprehensive View of Diverse Mitigation Measures, Biomaterials and Outlook}

\author{
Anu Mohandas ${ }^{1}{ }^{\circledR}$ Lin Shi $^{2}{ }^{\circledR}$, Seeram Ramakrishna ${ }^{1^{*}}(\mathbb{C}$ \\ ${ }^{1}$ Center for Nanotechnology \& Sustainability, Department of Mechanical Engineering, National University of Singapore, Singapore \\ ${ }^{2}$ Department of Medical Oncology, Jiangsu Cancer Hospital, Jiangsu Institute of Cancer Research, The Affiliated Cancer Hospital of \\ Nanjing Medical University, Nanjing, China \\ E-mail: seeram@nus.edu.sg
}

Received: 2 March 2021; Revised: 3 July 2021; Accepted: 3 July 2021

Abstract: COVID-19 the existing contagion is caused by Severe Acute Respiratory Syndrome Coronavirus 2 (SARS-CoV-2). As of 1st March, 2021, the statistical study shows, 114 million people all over the world have been affected by COVID-19 and in this about 2.53 million deaths have been reported with a recovery of 64.4 million cases. The most commonly testified signs of COVID-19 infection are pyrexia, tussis and tiredness; other symptoms that are less common include deprivation in senses (odor or flavor), pharyngitis, stuffy nose, cephalgia, gastroenteritis etc. Among the reported cases, approximately 10-15\% progress to severe disease and 5\% becomes critically ill. Most people recover at 2-6 weeks after exposure to the virus, but it is reported that there are some patients who may recur some symptoms for weeks or months after initial recovery although they are not infectious during this period. In this review article, we have briefly discussed the different diagnostic and detection measures that are being clinically practiced and the treatment methods including medicines and vaccines which has been undertaken in the fight against COVID-19. Recent advances in various regulatory measures comprising the application of biomaterials engineering (nanomaterials, biosensors, quantum dots, polymeric array-based vaccines, etc.) and the digital technologies are also discussed. Organoid cultures are also used against SARSCoV-2 to understand the biological phenomena taking place in the human body through infection, and thereby establishing the necessary trials to control the infection. In short, there is a requirement of the combination of study from multidisciplinary areas to understand the virus better and develop more effective mitigation measures. There are still studies under examination to improve the public health and to have complete control over this novel virus.

Keywords: SARS-CoV-2, diagnosis, personal protective equipment, medicine, vaccine, medical devices, digital technologies, biomaterials

\footnotetext{
Copyright (C2021 Seeram Ramakrishna, et al.

DOI: https://doi.org/10.37256/nat.222021806

This is an open-access article distributed under a CC BY license

(Creative Commons Attribution 4.0 International License)

https://creativecommons.org/licenses/by/4.0/
} 


\section{Flow diagram}

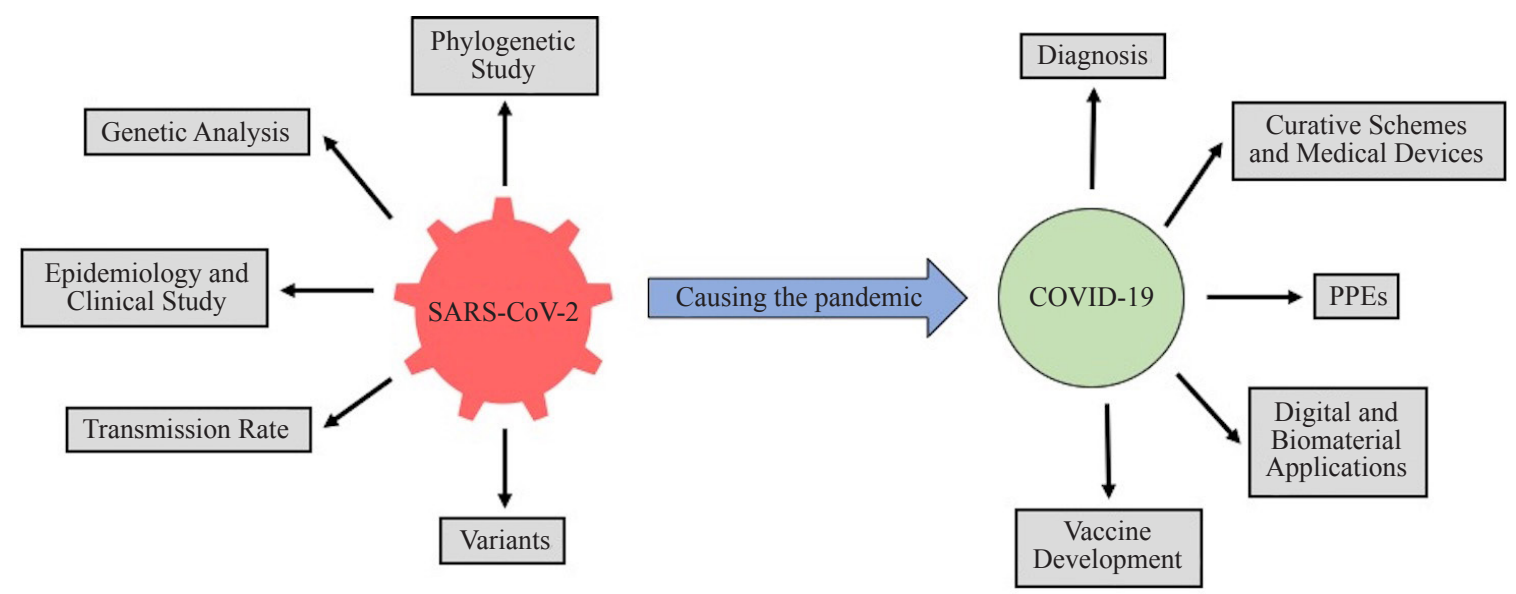

\section{Introduction}

In 2003, the pandemic Severe Acute Respiratory Syndrome (SARS) was spotted in Guangdong, China. This was caused by a coronavirus and later named SARS-CoV [1]. The name coronavirus, as corona symbolizes the coronetlike spikes on the external layer of the infectious agent. These viruses belong to the Coronaviridae family. They are insignificant in dimension (65-125 nm dia) containing an ss Ribonucleic Acid (26 to $32 \mathrm{kbs}$ in length) as a nucleic material. There are different subgroups for the coronavirus family and they are alpha (a), beta (b), gamma (g), and delta (d) coronavirus [2]. SARS-CoV belonged to the Beta coronavirus subgroup and the diseased patients exhibited symptoms of pneumonia alongside a distributed lung injury running to Acute Respiratory Distress Syndrome (ARDS). Later in 2012, Saudi Arabia was affected by another Beta group coronavirus called MERS-CoV (Middle East Respiratory Syndrome Coronavirus). The MERS-CoV infection starts with a minor upper lung injury leading to acute breathing disease. The patients suffer from a lung infection, accompanied by ARDS and collapsed kidneys, similar to SARS-coronavirus [3].

Recently, by the end of 2019, the outbreak of another Beta group coronavirus was reported from China at the seafood market in Wuhan. There was a continuous number of pneumonia cases reported by the Chinese management to the World Health Organization and the epidemiological study suggested it as viral pneumonia. Initially, it was suggested that people who visited the seafood market were only affected by the virus, but further investigation hinted that people having no records of exploring the seafood merchandise were also infected. This remark directed a person-to-person outspreading ability of the virus and consequently communicated in different countries other than China [4]. The multiplying of the virus from human to human appears because of the intimate interaction with a diseased individual, exposure to pertussis, sternutation, respirational drops, or spray. These droplets can infiltrate to human lungs through breathing via snout or jaws, subsequently initiating infection. The virus causing the infection is termed SARS-CoV-2 and the infection is COVID-19 by the International Committee on Taxonomy of Viruses (ICTV) [5]. The previous studies confirm that there is $79.5 \%$ similarity in the sequence of SARS-CoV-2 with SARS-CoV and $94.6 \%$ similar to SARS-CoV in the Open Reading Frame (ORF) $1 \mathrm{a} / \mathrm{b}$. However, there is only $40 \%$ similarity in the sequence of SARSCoV-2 with MERS-CoV. The prime differences between SARS-CoV-2 and SARS-CoV are in ORF3b, spike proteins, and ORF8. In SARS-CoV, the ORF8 activates pyroptotic apoptosis while it does not hold any functional domain in SARS-CoV-2 [6]. The transmission ability of the SARS-CoV-2 virus is superior to the SARS-CoV and this is because of the chromosomal reshuffling happening at the spike amino acid chain in the Receptor-Binding Domain of the pathogen SARS-CoV-2 [2]. Though genetic confirmation implies that severe acute respiratory syndrome coronavirus 2 is a normal virus, possibly instigated in animals, we have no validation about how and when the virus originally inputted humans [7]. 


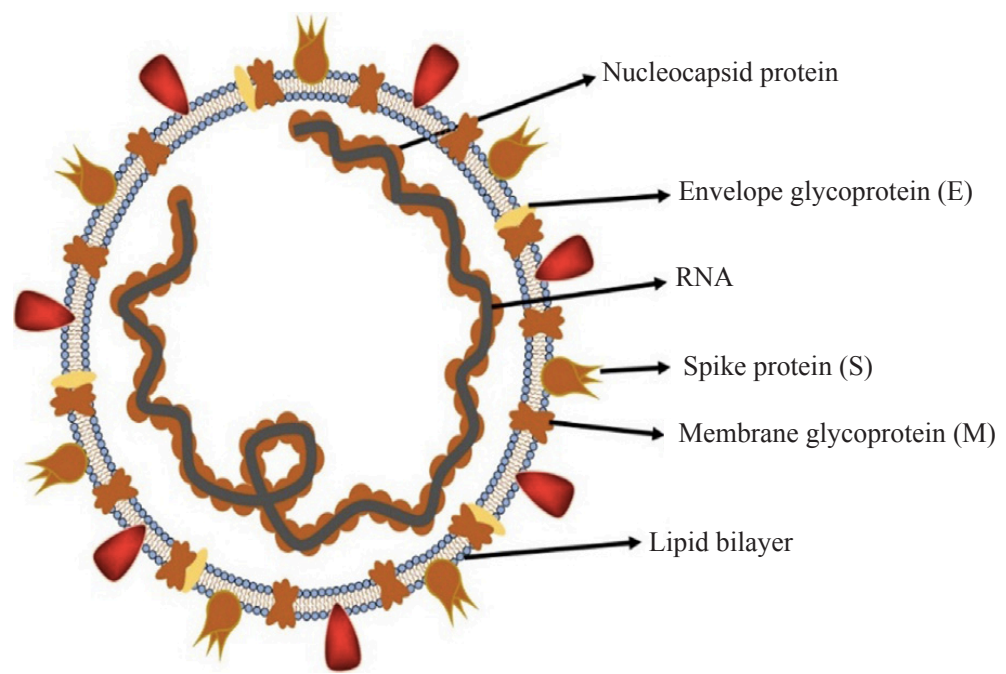

Figure 1. Structure of coronavirus, Figure only reprinted from ref. [2], Copyrights Elsevier Publications on behalf of Cairo University

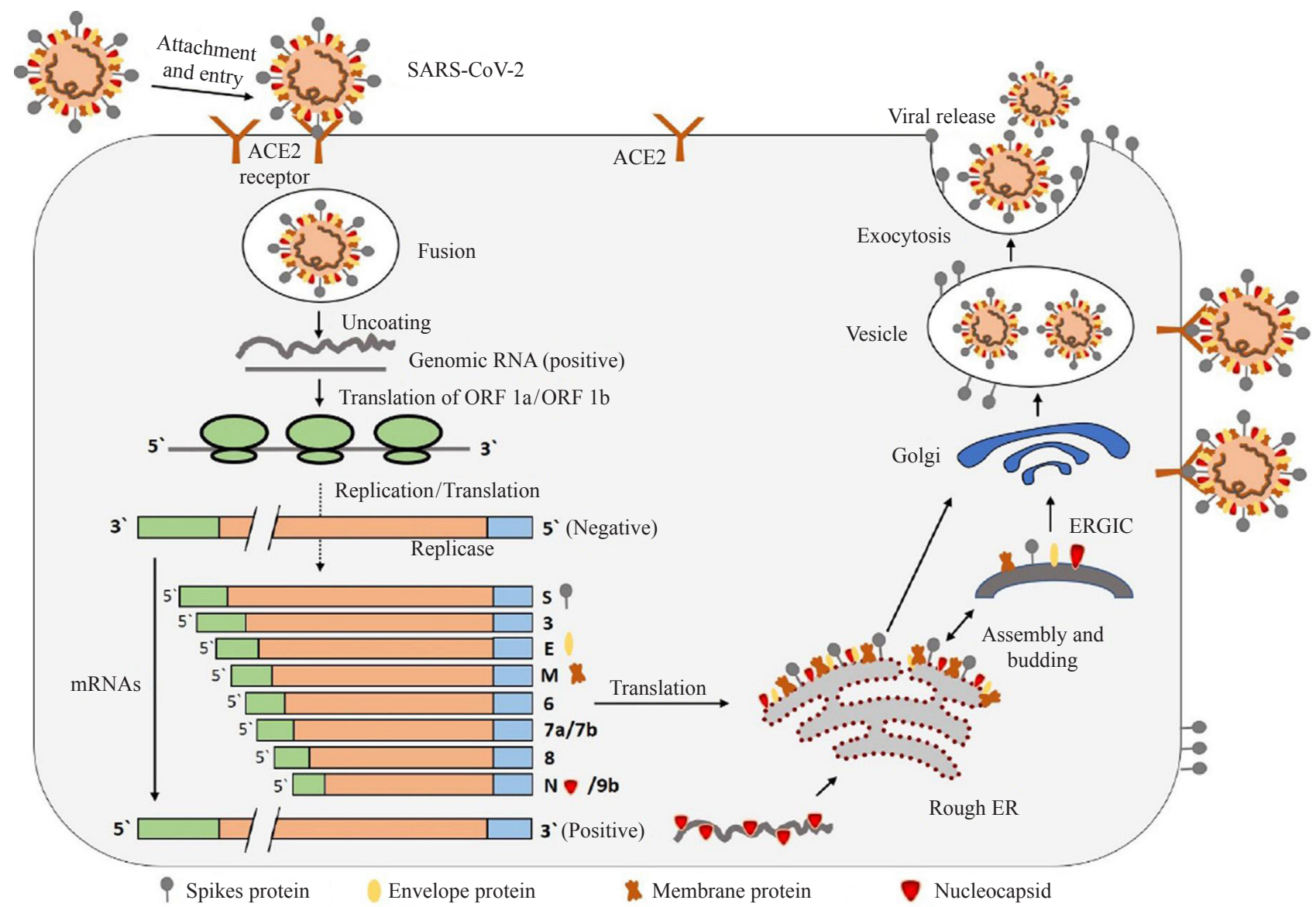

Figure 2. The biological clock of SARS-CoV-2 in the host cell. ACE2-angiotensin-converting enzyme 2; mRNAs-messenger RNA; ER-endoplasmic reticulum; ERGIC-ER-Golgi intermediate compartment, Figure only reprinted from ref. [2], Copyrights Elsevier Publications on behalf of Cairo Universityy 


\subsection{Structure and mechanism of human coronaviruses}

Specified chromosomes in open reading frame 1 regions of coronavirus encode proteins for viral replication, spikes development, and formation of the viral capsid enclosing the genome [8]. The virus binds and enters into the host chamber with the thorn-like structure on its exterior surface (Figure 1). The receptor to which the virus (SARS-CoV) attaches to a host cell is the Angiotensin-Converting Enzyme 2 (ACE2).

The life cycle of the virus starts once the $\mathrm{S}$ amino acid chain fixes to the cell-surface effector ACE2 on the host cells, which instigates a configurational conversion in S polypeptide allowing the pathological sheath to blend with the cytomembrane within the endosomal channel. The viral genome is discharged to the host cell and it undertakes translational machinery to engender its polyproteins (pp) $1 \mathrm{a}$ and $1 \mathrm{~b}$. These pp are then slashed into tiny commodities by viral proteases. Later transcription takes place with polymerase and produces subgenomic mRNAs which are deciphered into significant amino acid chains vital for the virus. These proteins and genetic material are collected into an extracellular virulent form of the virus in the endoplasmic reticulum and Golgi-body and then transferred through the cytoplasm and discharged exterior to the cell membrane [2]. Figure 2 represents the life cycle of SARS-CoV-2 in a host cell.

\subsection{Clinical symptoms of SARS-CoV-2 infected patients}

Frequent manifestation comprises:

- Pyrexia, tussis, muscle pain, and feeling exhausted;

- Gastroenteritis and emesis few dates afore fever;

- Some has cephalgia or haemoptysis and be moderately symptomless;

- Patients (male) aged older with symptomatology are supplemental to develop lung breakdown;

- Ordinary or inferior WBCs, blood disorder, thrombopenia, with prolonged stimulated thrombokinase, and boosted $\mathrm{C}$-reactive molecules are also observed in patients.

Adults of any stage having definite health ailments (diabetes, hypertension, cardiovascular disease, etc.) are at high probability for acute infection from the SARS-CoV-2 virus. The acute infection meaning hospitalization, admission to the ICU, intubation or mechanical ventilator, or death. It is observed that during the onset of disease, individuals might have ordinary or inferior WBCs, blood disorder, thrombopenia, with prolonged stimulated thrombokinase, and boosted C-reactive molecule level. So, patients with temperature and superior inhaling symptoms with lymphopenia/leukopenia are supposed to have covid-19 [9-11]. As an influence of the pandemic, the psychological fitness of the people is also affected due to poor physical health, social isolation, job loss, and income insecurity [12].

There are several biological health factors like gender, age, high-pitched blood pressure, lung and heart diseases that directly relate to COVID-19 infection. Lately, a consortium amongst blood group types and the different phases of COVID-19 infection has been recognized. It is understood that the genetic code of the blood groups is mirroring for the pathogenesis of the pandemic by distressing the receptor molecules, the intensity of the protein carrying oxygen in the blood, erythrocyte sum, influences heart attack, blood clots in the vein, etc. This headed to the contemplation of a straight link of the blood groups (A, B, AB, O, and Rh types) with the COVID-19 [13]. Zhao et al. were the first group to study the connection between the infection of COVID-19 and blood groups. They identified the blood groups of 2,173 COVID-19 positive patients and observed that advanced threat of the pathogenic infection was observed in individuals with $\mathrm{A}$ blood type than the $\mathrm{B}$ and $\mathrm{AB}$ groups and an inferior chance of contagion was seen in individuals with $\mathrm{O}$ type blood group [14]. Similar observations were obtained by Zietz and his colleagues where they investigated the infection, hospitalization with ventilator, and death due to COVID-19. They studied the blood groups of 14,112 positive cases of SARS-CoV-2 and found that a greater probability of infection was more for people with A blood group, while hospitalization with ventilator was high among $\mathrm{B}$ and $\mathrm{AB}$ blood types and individuals with $\mathrm{AB}$ blood group showed an increased possibility of death. They also had an interesting remark about Rh blood type, that the Rh-negative blood groups indicated a reduced effect on infection, ventilation, and death [13]. Ellinghaus et al. had a different observation regarding the ventilation of COVID-19 patients. The authors found a reduced risk of ventilation for people with blood groups $\mathrm{A}, \mathrm{B}$, or $\mathrm{AB}$ which is contradicting the other researchers, even though their results were not statistically substantial [15]. This suggests further verification requisite for identifying the relation between blood groups and COVID-19 infection, which can be exploited in the future for the documentation of vulnerable individuals at the 
different stages of infection and deliver the necessitous health care supplies before aggravating their condition. In our review, we are briefly discussing the different diagnostic tests, preventive and medication measures, which have been accomplished clinically, and some of the recent advances which are being carried out to control COVID-19. Another topic that has been articulated is the applications of biomaterial engineering in the above-mentioned subjects.

\section{Diagnostic tests}

The main emphasis of treatment and control is the rapid and early laboratory identification of COVID-19. The foremost job for the medical diagnosis is to check any past manifestation or intimate communication with COVID-19 infected folks during the past 2 weeks. The biochemical characterization of SARS-CoV-2 genetic code is the most accepted laboratory test. Commercially there are many viral nucleic acid detection kits directing Open Reading Frames (ORF) $1 \mathrm{~b}$ including S, RdRp-RNA dependent RNA polymerase, $\mathrm{N}$ or E genes. The biochemical exposure is disturbed by numerous aspects which could give false negatives, so different detection techniques should be adopted to verify COVID-19. Another method used was the chest Computed Tomography (CT), which disclosed distinctive structures on preliminary $\mathrm{CT}$, comprising multiple lobes that are conjoint on both sides with a marginal or outer dispersal in COVID-19 patients. Xingzhi et. al, did a study in which they used CT as a screening tool to detect COVID-19 positive patients (5 patients), who were giving a negative result for initial real time quantification RT-PCR test [16]. Thus, frequent PCR tests joined with CT visualizing should be used for entities with peak medical speculation of COVID-19 [7]. The different laboratory diagnostic tests are reviewed below.

\subsection{Neutralization tests}

The two types are conventional Virus Neutralization Test (cVNT) and pseudovirus-based VNT (pVNT). The test determines the antibodies in blood samples that can biologically countervail the repercussion of a pathogen. Both techniques need treatment of the virus SARS-CoV-2 in a professional biosafety cabinet provision; Biosafety Level 3 (BSL3) for cVNT; BSL2 for pVNT. The major disadvantage of this technique is that it is tedious and takes 2-4 days to complete. A group of scientists demonstrated a study in which they are using a substitute/surrogate Virus Neutralization Test (sVNT) experiment to encounter Neutralising Antibodies (NAbs) which targets the viral S polypeptide ReceptorBinding Domain (RBD) in a BSL2 laboratory within 1-2 hrs. They mimicked the virus (RBD)-host (ACE2) interaction in an ELISA (enzyme-linked immunosorbent assay) plate well and found that this interplay could be shut off by specific NAbs in the blood serum exercising the criteria of cVNT. Though cVNT cannot be completely replaced by sVNT, they have shown an approach with enhanced sensitivity (95\% to 100\%) and specificity (99.93\%) to detect NAbs which is easy, rapid, and safe as it does not require live cells/virus for the experiment. The major advantage of this technique (sVNT) is that it can be employed to detect the pathogenic viral antibodies in a genus-independent and isotype-free manner. It also plays an important role in the assessment of vaccine efficacy during the clinical studies of the vaccine candidates [17]. Another factor that needs to be monitored is that the mutations taking place are SARS-CoV-2, which can affect these antibody assays by altering the ability of the assays in detecting the specific antibodies relating to nucleocapsid and viral spike proteins. Researchers are currently focussing on these factors and its assessment is in advance [18].

\subsection{Nucleic acid tests}

Recent advancements in molecular biology techniques have led to developments in nucleic acid detection methods, especially methods based on Polymerase Chain Reaction (PCR), which is considered as a quintessential detection method for viruses. The confirmation test for COVID-19 accepted and recommended by the World Health Organisation (WHO) is the Reverse Transcriptase-Polymerase Chain Reaction (RT-PCR) [19]. Commercially there are many RTPCR characteristic kits available for diagnosing the virus of the pandemic. A group of scientists studied and compared 7 industrially accessible tools for testing multiple tests. The seven RT-PCR tools for detecting SARS-CoV-2 in the study include TRUPCR, Taq path, Allplex, Patho detect, LabGun, Fosun, and BGI. These kits were used on 40 positive cases and 10 negative cases of COVID-19 trials. They concluded their study by saying that all the kits which have been 
mentioned in their evaluation could be employed for the accurate and definite prognosis of the SARS-CoV-2 virus; and for accomplishing multiple sample screening, they suggest using TRUPCR, Taq path, Allplex, and BGI RT-PCR kits based on their results [20]. Puck et al. did a similar study, where he compared 7 RT-PCR instruments (R-Biopharm AG, PrimerDesign, CerTest Biotec, Seegene, BGI, Altona Diagnostics, and KH Medical) and concluded that all the kits mentioned above could be applied for the regular detection of symptom exhibiting victims. While carrying out in a population with a little amount of viral RNA like health practitioners or patients in later stages of infection, use the best-accomplished tools for identifying the positive SARS-CoV-2 cases. In their study, those kits are R-Biopharm AG, Seegene, BGI, and KH Medical [21].

Below is the Table (Table 1) discussing different types of nucleic acid tests including RT-PCR and their working principles.

Table 1. Molecular Diagnostics test for COVID-19 recognition (Based on ref. [19], with actualization and addition)

\begin{tabular}{|c|c|c|c|c|c|}
\hline Methods & Working principle & Testing layout & Advantages & Disadvantages & References \\
\hline qRT-PCR & $\begin{array}{c}\text { Viral RNA is reverse } \\
\text { transcribed into } \\
\text { complementary DNA (cDNA), } \\
\text { following amplification of its } \\
\text { specific regions; fluorescent } \\
\text { signals are detected }\end{array}$ & $\begin{array}{c}\text { Biosafety cabinet-class II, } \\
\text { epidemiology institutes, } \\
\text { quarantine hub }\end{array}$ & $\begin{array}{l}\text { Specific, economical } \\
\text { equipment, time-saving }\end{array}$ & $\begin{array}{l}\text { Incorrect scores, Intricate } \\
\text { preliminary operation, } \\
\text { involves expert }\end{array}$ & {$[22,23]$} \\
\hline $\begin{array}{l}\text { Droplet digital PCR } \\
\text { (ddPCR) }\end{array}$ & $\begin{array}{l}\text { Utilizing water-oil suspension } \\
\text { in conventional PCR; sample is } \\
\text { split into tiny drops of fluid and } \\
\text { amplifying each drop } \\
\text { comprising the } \\
\text { target using PCR }\end{array}$ & $\begin{array}{c}\text { Biosafety cabinet-class II, } \\
\text { epidemiology institutes, } \\
\text { quarantine hub }\end{array}$ & $\begin{array}{c}\text { Measurable, tactful, } \\
\text { distinguish samples with } \\
\text { little amount of viral } \\
\text { RNA, free of } \\
\text { a calibration curve }\end{array}$ & $\begin{array}{l}\text { Subject to external } \\
\text { contamination, costly, } \\
\text { standardizing essential }\end{array}$ & {$[24]$} \\
\hline Nested RT-PCR & $\begin{array}{c}2 \text { successive PCRs reducing } \\
\text { non-specific amplification } \\
\text { of DNA }\end{array}$ & $\begin{array}{l}\text { Biosafety cabinet-class II, } \\
\text { the office of a perfect } \\
\text { and municipal } \\
\text { epidemiology institutes, } \\
\text { quarantine hub }\end{array}$ & $\begin{array}{c}\text { Sensitive, more specific } \\
\text { than RT-PCR, can detect } \\
\text { low-copy-number viruses, } \\
\text { time-saving }\end{array}$ & $\begin{array}{l}\text { Intricate preliminary } \\
\text { operation, involves expert } \\
\text { and workforce, } \\
\text { contamination in } \\
\text { second PCR }\end{array}$ & {$[25]$} \\
\hline RT-LAMP & $\begin{array}{c}1 \text { step nucleic acid } \\
\text { amplification method; auto } \\
\text { cycling strand displacement } \\
\text { DNA synthesis; } 2 \text { pairs of } \\
\text { primers used } \\
\text { (inner and outer primers) }\end{array}$ & $\begin{array}{l}\text { Rudimentary workrooms, } \\
\text { civic treatment spots }\end{array}$ & $\begin{array}{l}\text { Efficient, relating to a } \\
\text { thermostat, susceptible, } \\
\text { convenient, } \\
\text { free of advanced } \\
\text { apparatus }\end{array}$ & $\begin{array}{l}\text { Easily spoiled and } \\
\text { incorrect affirmative } \\
\text { results, negligent } \\
\text { magnification, } \\
\text { requires expert }\end{array}$ & {$[26]$} \\
\hline $\begin{array}{l}\text { Portable } \\
\text { benchtop-sized } \\
\text { analyzers }\end{array}$ & $\begin{array}{c}\text { Expeditious and test done at } \\
\text { or near patient care; } \\
\text { automated molecular } \\
\text { diagnostics }\end{array}$ & $\begin{array}{l}\text { Medical labs, doctor's } \\
\text { workplace, } \\
\text { emergency divisions }\end{array}$ & $\begin{array}{l}\text { Efficient, relating to a } \\
\text { thermostat, susceptible, } \\
\text { convenient, } \\
\text { free of advanced } \\
\text { apparatus }\end{array}$ & $\begin{array}{l}\text { Unreliable, not suitable } \\
\text { for faintly positive trials }\end{array}$ & {$[27,28]$} \\
\hline $\begin{array}{l}\text { Nanoparticles-based } \\
\text { amplification }\end{array}$ & $\begin{array}{l}\text { Nanoparticles (e.g. gold } \\
\text { nanoparticles) incorporated in } \\
\text { nucleic acid amplification to } \\
\text { develop a colorimetric test }\end{array}$ & $\begin{array}{c}\text { Biosafety cabinet-class II, } \\
\text { organizations examining } \\
\text { the habitat and climate }\end{array}$ & $\begin{array}{c}\text { Sensitive, implemented } \\
\text { with trained RNA } \\
\text { abstraction routines, } \\
\text { exceptional RNA binding } \\
\text { performances }\end{array}$ & $\begin{array}{l}\text { Intricate preliminary } \\
\text { operation, demands } \\
\text { expert, costly, risk of } \\
\text { photobleaching }\end{array}$ & {$[29,30]$} \\
\hline
\end{tabular}

\subsection{Antigen test for COVID-19 detection}

The different SARS-CoV-2 proteins are S, M, E, and N proteins; in which the immunogenic targets $(\mathrm{N}$ and $\mathrm{S})$ are widely used against the antibodies for the antigen test. It is a rapid immunoassay for the recognition of COVID-19 immunogens. The sample preparation is done by eluting the sample from the swab into an extraction buffer solution. The test is initiated by adding the extracted sample into the well of the assay device. As the trial moves in the assay strip, the immunoglobulins combined with the indicator will attach to the pathogenic epitope and arrest molecules assembling an antigen-antibody complex. As the complex migrates through the strip, it is seized on the trial line in a matrix. The 
presence of coloured lines at the control and test region signifies a positive case of COVID-19 and the single line only at the control region indicates negative test results. The advantage of this test is that it is portable, sensitive, and rapid (10-15 minutes) but there are limitations like false-negative results on patients taking high doses of biotin [31]. Bo et al. tested the liquid body waste and the nasal swab samples to detect the nucleocapsid polypeptide of the pandemic virus using a fluorescence immunochromatographic assay. They took samples from 239 patients with suspected COVID-19 and did the RT-PCR test as the benchmark. In accordance with the nucleic acid test, they got 100\% nucleocapsid proteinpositive and negative test results; thus indicating the nucleocapsid protein assay as a rapid, easy, and accurate method for diagnosis of COVID-19 [32].

\subsection{Immunological diagnostics}

When there is an infection, the immune system activates the IgG, IgM, and IgA antibodies and these antibody types can be determined by some specific reagents. The IgM is produced within 5-7 days after COVID-19 infection and this is utilized for identifying recent infections. IgG will be produced within 10-15 days after infection. The presence of these antibodies in a COVID-19 suspected body can be utilized as a diagnostic measure [19]. Niko et al. did a study focusing on IgG antibodies and compared the performance of 2 ELISA assays (Euroimmum and Vircell) with 1 lateral flow test or rapid test (FaStep) and 2 on-site assays (Plaque Reduction Neutralization Test (PRNT) and Immunofluorescence Assay (IFA)). The sensitivity of these mentioned assays was in the range of 58.8-76.5\% for the primary stage of contagion and 93.8-100\% for later stages of the infection [33]. Table 2 is discussing the different immunological assays for testing the COVID-19 virus.

Table 2. Immunological tests for SARS-CoV-2 (Based on ref. [19], with actualization \& addition)

\begin{tabular}{|c|c|c|c|c|c|}
\hline Methods & Working principle & Testing layout & Advantages & Disadvantages & References \\
\hline ELISA & $\begin{array}{l}\text { Includes an enzyme-labelled antigen/ } \\
\text { antibody; the enzyme activity is } \\
\text { measured by the addition of a substrate, } \\
\text { causing color change } \\
\text { and measured colorimetrically }\end{array}$ & $\begin{array}{l}\text { Medical labs, } \\
\text { epidemiology } \\
\text { institutes }\end{array}$ & $\begin{array}{l}\text { Measurable, effortless, } \\
\text { stable reagent, } \\
\text { less portable } \\
\text { to infection }\end{array}$ & $\begin{array}{l}\text { Laborious, sensitivity is } \\
\text { less, antibody reacts to } \\
\text { analogous antigens } \\
\text { on unique protein, } \\
\text { usage of luxurious } \\
\text { monoclonal antibody, } \\
\text { underperforming }\end{array}$ & [34] \\
\hline $\begin{array}{l}\text { Lateral Flow Assay } \\
\text { (LFA) }\end{array}$ & $\begin{array}{l}\text { With the help of capillary action, } \\
\text { the liquid sample containing the } \\
\text { analyte is allowed to move through a } \\
\text { polymeric strip containing molecules } \\
\text { that can interact with the analyte; } \\
\text { and attaching the analyte }\end{array}$ & $\begin{array}{l}\text { Medical labs, } \\
\text { doctor's workplace, } \\
\text { catastrophe } \\
\text { divisions, welfare } \\
\text { locations }\end{array}$ & $\begin{array}{l}\text { Expeditious, } \\
\text { expedient, } \\
\text { in-house safeguard, } \\
\text { reasonable, } \\
\text { minute test size }\end{array}$ & $\begin{array}{l}\text { Low susceptive, } \\
\text { cross-reactant, varying } \\
\text { functioning, primary } \\
\text { analysis-not suitable, } \\
\text { truncated yield }\end{array}$ & [35] \\
\hline $\begin{array}{l}\text { Microarray and } \\
\text { microfluidic } \\
\text { chip }\end{array}$ & $\begin{array}{l}\text { Mounting of single or multiple lab } \\
\text { processes in a chip format }\end{array}$ & $\begin{array}{l}\text { Medical labs, } \\
\text { catastrophe } \\
\text { divisions, } \\
\text { welfare locations }\end{array}$ & $\begin{array}{l}\text { Minute in size, } \\
\text { sensitive, programmed, } \\
\text { elevated yield, } \\
\text { transportable }\end{array}$ & $\begin{array}{l}\text { Fundamental skills } \\
\text { require principles and } \\
\text { patterns, costly, } \\
\text { indistinct attachment } \\
\text { of polypeptides }\end{array}$ & [36] \\
\hline IFA & $\begin{array}{l}\text { Specificity of the antibody to } \\
\text { their antigens }\end{array}$ & $\begin{array}{l}\text { Medical labs, } \\
\text { biosafety cabinet } \\
\text { managing } \\
\text { infectious means, } \\
\text { epidemiology } \\
\text { institutes }\end{array}$ & $\begin{array}{l}\text { Intervention of } \\
\text { autonomous biotin and } \\
\text { adulteration of } \\
\text { allergens in the } \\
\text { bloodstream is avoided }\end{array}$ & $\begin{array}{l}\text { Negligent illumination, } \\
\text { truncated yield, } \\
\text { laborious }\end{array}$ & [37] \\
\hline $\begin{array}{l}\text { Chemiluminescence } \\
\text { Immunoassay } \\
\text { (CLIA) }\end{array}$ & $\begin{array}{l}\text { The levels of antigen-antibody complex } \\
\text { are estimated using a labelled antibody } \\
\text { when the paratope of the antibody binds } \\
\text { to the epitope of antigen }\end{array}$ & $\begin{array}{l}\text { Medical labs, } \\
\text { epidemiology } \\
\text { institutes }\end{array}$ & $\begin{array}{l}\text { Programmed, } \\
\text { expeditious, } \\
\text { measurable analysis, } \\
\text { sensitive, wide-range } \\
\text { in linear measure, } \\
\text { steady scores }\end{array}$ & $\begin{array}{l}\text { Advanced apparatus, } \\
\text { whole blood } \\
\text { samples-not suitable }\end{array}$ & [38] \\
\hline
\end{tabular}




\subsection{Genome sequencing}

The different genomes of SARS-CoV-2 are available at public repositories involving China National GeneBank DataBase (CNGBdb), National Center of Biotechnology Information (NCBI) GenBank, and Global Initiative on Sharing All Influenza Data (GISAID) [19]. The characterization of genetic material is the tool used to collect the genetic information of the virus which gives way to tackle the viral outbreak and also to develop treatment therapies and vaccines. Distinct research groups have done studies on the viral genome to get the genetic idea about the SARSCoV-2. Roujian and his group did the metatranscriptomic sequencing on samples taken from nine COVID-19 patients. They obtained 10 genome sequences from the samples which were similar and showed $99.98 \%$ sequence identity. This study helped them to indicate that COVID-19 viruses have instigated from a matching origin [39]. Table 3 categorizes the different genome sequencing tests for SARS-CoV-2.

Table 3. Characterizing genetic material in SARS-CoV-2 (Based on ref. [19], with actualization \& addition)

\begin{tabular}{|c|c|c|c|c|c|}
\hline Methods & Working principle & Testing layout & Advantages & Disadvantages & References \\
\hline $\begin{array}{l}\text { Metatranscriptomic } \\
\text { sequencing }\end{array}$ & $\begin{array}{l}\text { Sequence random mRNAs to } \\
\text { recognize the regulation of } \\
\text { complex processes in a pathogen }\end{array}$ & $\begin{array}{l}\text { Biosafety cabinet- } \\
\text { class II, familial } \\
\text { analysis centers, } \\
\text { experimental labs }\end{array}$ & $\begin{array}{l}\text { Effortless, reference } \\
\text { sequence not } \\
\text { required }\end{array}$ & $\begin{array}{l}\text { Costly, advanced } \\
\text { apparatus, insufficient } \\
\text { scope and measure }\end{array}$ & {$[40,41]$} \\
\hline Amplicon sequencing & $\begin{array}{c}\text { PCR is used to create DNA } \\
\text { sequences called amplicons, } \\
\text { which is utilized to analyze } \\
\text { genetic variation in } \\
\text { specific genomic regions }\end{array}$ & $\begin{array}{l}\text { Biosafety cabinet- } \\
\text { class II, familial } \\
\text { analysis centers, } \\
\text { experimental labs }\end{array}$ & $\begin{array}{l}\text { Timely, sensitive, } \\
\text { distinguish samples } \\
\text { with little amount } \\
\text { of viral RNA, } \\
\text { low-budget }\end{array}$ & $\begin{array}{l}\text { Advanced apparatus, } \\
\text { vastly varying } \\
\text { sequences-not suitable }\end{array}$ & {$[42]$} \\
\hline $\begin{array}{l}\text { Hybrid capture-based } \\
\text { sequencing }\end{array}$ & $\begin{array}{l}\text { Used to identify novel variants } \\
\text { and has higher mutation } \\
\text { resolution; can sequence a specific } \\
\text { region of the genomic sequence } \\
\text { which are relevant for } \\
\text { a particular research }\end{array}$ & $\begin{array}{l}\text { Biosafety cabinet- } \\
\text { class II, familial } \\
\text { analysis centers, } \\
\text { experimental labs }\end{array}$ & $\begin{array}{l}\text { Highly sensitive, } \\
\text { detect variability } \\
\text { within individual }\end{array}$ & $\begin{array}{l}\text { Advanced apparatus, } \\
\text { vastly varying } \\
\text { sequences-not suitable }\end{array}$ & {$[42]$} \\
\hline $\begin{array}{l}\text { Nanopore targeted } \\
\text { sequencing }\end{array}$ & $\begin{array}{l}\text { A nucleotide is moved through } \\
\text { a nanopore immersed in a } \\
\text { conducting medium with } \\
\text { applied voltage; causing a current } \\
\text { change, which can be read and } \\
\text { utilized to sequence the nucleotide }\end{array}$ & $\begin{array}{l}\text { Biosafety cabinet- } \\
\text { class II, familial } \\
\text { analysis centers, } \\
\text { experimental labs }\end{array}$ & $\begin{array}{l}\text { Spotting range is } \\
\text { broad, expeditious } \\
\text { managing phase, } \\
\text { precise, display } \\
\text { discrepancy }\end{array}$ & $\begin{array}{l}\text { Costly, } \\
\text { advanced apparatus, } \\
\text { demands expert }\end{array}$ & [43] \\
\hline
\end{tabular}

\subsection{Isothermal amplification with CRISPR technology}

The breakthrough of microbial defense mechanism CRISPR and CRISPR-associated (Cas) proteins, tip to the CRISPR-based diagnostics. Different Cas proteins are used for analytical applications. Recent studies have been developed by incorporating isothermal amplification with CRISPR techniques (using CRISPR-associated proteins 12 and 13) detecting COVID-19 virus. Both proteins show diverse functions; Cas12 nuclease aims for single-stranded DNA and Cas13 focuses on single-stranded RNA. Cas12 demands a small definite series succeeding the objective DNA sequence, also known as protospacer adjacent motifs (PAM), which assists the disentangling of the targeted dsDNA and the attachment of CRISPR RNA (crRNA) to the targets (DNA). This brings a conformity alteration in Cas 12 triggering splitting activity to slice any single-stranded DNA broadly [44]. This is not the case for Cas13, it selects the primary nucleoside monophosphate or diphosphate or triphosphate consequent to the 3 ' end of directing sequence and chops ssRNA nonspecifically [45]. 


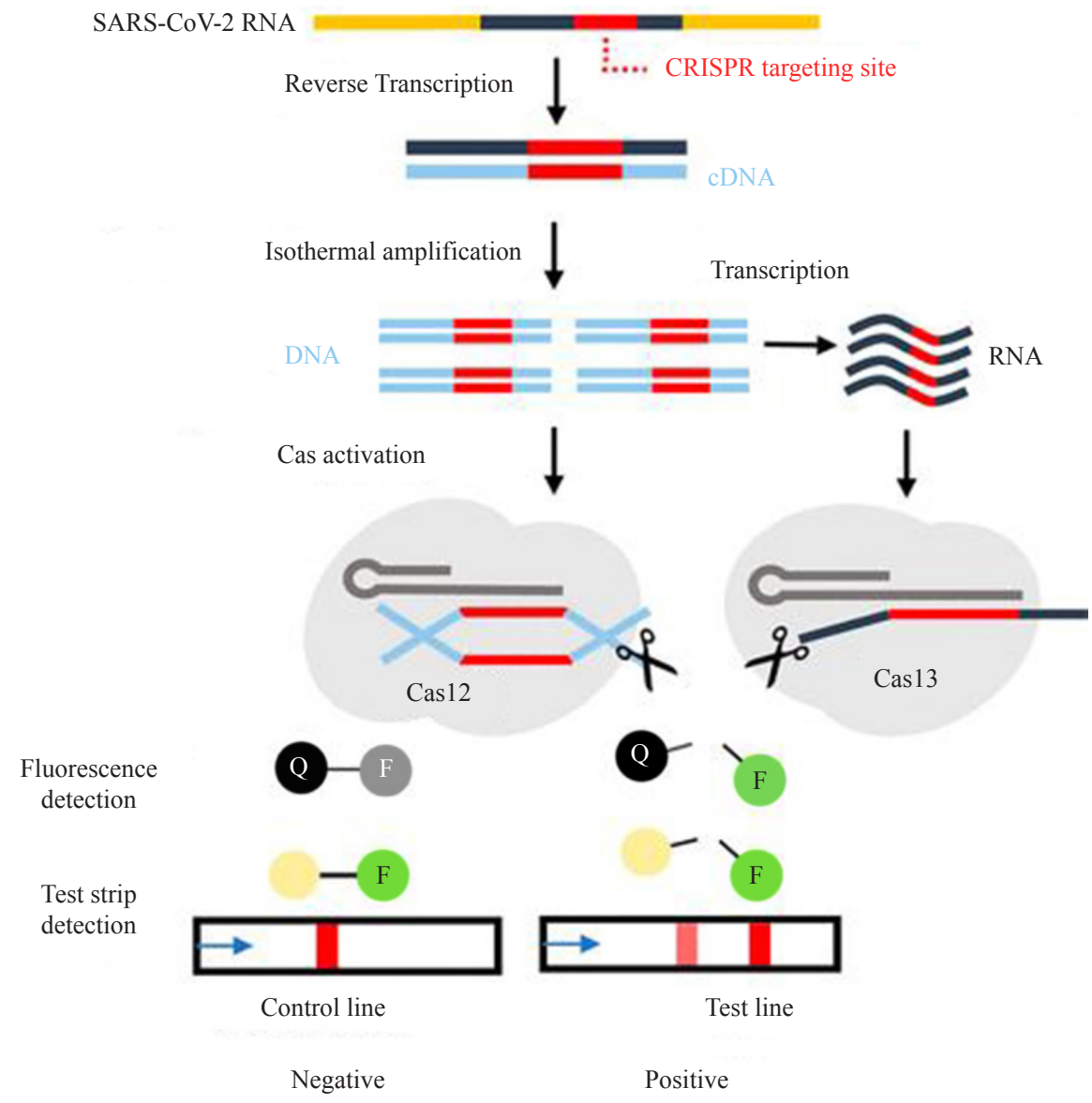

Figure 3. Schematic representation of CRISPR technique incorporated with isothermal amplification for detecting SARS-CoV-2, Figure only reprinted with permission from ref. [46], Copyrights ACS Publications

This CRISPR technique is incorporated with the isothermal amplification (Figure 3 is the schematic representation of this) in which the signaling reporters (short, ss DNA/RNA) are bilaterally marked with a fluorochrome and a substance that decreases the fluorescence intensity (quencher). When the signaling reporter is cleaved, the quencher separates from the fluorochrome and restores visible sign, which is projected below the LED. Another methodology is detecting on a test strip by dually labeling a substrate with biotin (to intensify effectiveness) and probe-Fluorescein Amidite (FAM). The flow strip is modified by coating gold nanoparticles (AuNPs) to anti-FAM antibodies to block FAM. Reporters stay unbroken if there is no target and will be held on a reference line through streptavidin, signifying a negative test by accumulating AuNPs and generating red color. When there is a target, the reporters are broken by activated Cas polypeptide and release FAM, to travel with AuNPs to the test mark, representing a positive test with another red color [46]. More authorization is vital in operating CRISPR-centered practices for diagnosing the SARS$\mathrm{CoV}-2$ virus. James et al. described a study in which they developed a rapid and error-free CRISPR-Cas12-grounded protocol aimed at diagnosing COVID-19 by means of RNA isolated from the nasal swab. The protocol was centered on DETECTR (DNA Endonuclease-Targeted CRISPR Trans Reporter), which amplifies genetic material utilizing RT-LAMP, later recognizing and splitting target sequences by Cas12. The results were obtained from lateral flow strips as readout signals (30-40minutes) and obtained 10 copies/microliter of SARS-CoV-2 RNA [47]. This CRISPRbased technology can be further developed as a bedside examination of the COVID-19 virus accomplished by nonlaboratorians. 


\subsection{Detection devices}

Environmental contamination by microbes and viruses is one of the major causes of widespread human infectious diseases. Here comes the importance of environmental cleaning practices. There are methods to measure the cleanliness of a surface which include Adenosine Triphosphate (ATP) scrutinizing, optical examination, pathological assay, incandescent indicators/creams. The fastest among these is ATP monitoring, which measures the organic matter that may remain on a surface after cleaning. The Adenosine Triphosphate is an enzyme present in all organic matter; so, the person conducting ATP monitoring, swabs the surface to be tested and insert that swab into a handheld machine, luminometer, the results are available within seconds [48]. The result obtained is an indirect measure of cell density. Viruses do not store ATP but utilize them to replicate when associated with living cells. Thus, ATP is a generic marker of biological contamination and thereby indirectly, monitors the potential viral contamination [49]. Laura et al. studied a surrogate approach of ATP monitoring on MS-2 phage. The study demonstrated that the hygienic interventions in a workplace resulted in a substantial drop of viral uncleanness, which is supervised by means of a prompt skill (ATP monitoring). Consequently, the extent of hygiene stated with a quantifiable tool is associated with the expansion of viruses and can be adopted to assess possible viral interferences [50].

\section{Personal protective equipment}

The healthier way to fight against COVID-19 is to follow some preventive measures to avoid contact with the virus. The general preventive tools involve an active superficial antiseptic, hand sanitation, Personal Protective Equipment (PPE) including facial mask, maxillofacial, and optic guard.

\subsection{Surface disinfectant}

Some of the active compounds exhibiting virucidal activity include alcohol (isopropanol, phenic acid, ethyl alcohol), quats/quaternary ammonium compounds, chloranol/hypochlorous acid, perhydroxic acid, very responsive chemical mixtures (formic aldehyde, acetaldehyde, etc.), tricarboxylic acid, caprylic acid. Figure 4 is the schematic representation of the effect of disinfectants on coronavirus. It basically denatures the lipid bilayer of the virus and ultimately damages the genetic material. Alcohols, ethanol (78-95\%), and isopropanol (70-100\%)-an effective disinfectant deactivating phospholipid encircled virus in 2 minutes and has an insignificant toxic effect on human skin. But some studies show that the frequent use of these disinfectants can lead to serious health issues like respiratory problems, slowing down brain activity, liver damage, kidney failure [51]. Quaternary Ammonium Compounds (QACs) -positively charged nitrogen at the center bounded by halogen which is negatively charged. Differences in the nuclear dimension, string measurement, and $\mathrm{pH}$ select the bactericidal capacity of the complex. Another group is the group 17 elements i.e., chloranol/hypochlorous acid ( $\mathrm{HOCl})$, antiformin/sodium hypochlorite $(\mathrm{NaOCl})$. They selectively bind to the unsaturated connections of fatty acid sheets (virus) which interrupts membrane integrity and upturns penetrability. Relatively $\mathrm{HOCl}$ is a stronger oxidant than $\mathrm{NaOCl}$. The added purifiers involve bleaching agents and peroxy acidsinduce free radicals (perhydroxic acid radicals, hydroxides, dioxides, peroxides) to corrode fundamental phosphatides, genetic material, and polypeptides that prime to antiviral action [52]. Phenol-based disinfectants are used in hospitals. At a concentration of $0.5-5 \%$, the phenic acid products can neutralize viruses like HIV and other viruses with waterinteracting shells by stimulating outer layer destruction leading to seepage of cytosols and deteriorating protein [53, 54].

For disinfecting medical devices and surgical equipment, formic aldehyde and glutaraldehyde are widely used in which the use of formic aldehyde is limited due to its strong odor and is a possible carcinogen. Their mechanism of action is by alkylating the proteins and nucleic acid of the pathogens and is used as a disinfecting agent against coronavirus at a concentration of 0.5 to 3\% (2 minutes exposure time) [54-56]. Gunter's experimental evidence suggests that 78 to $95 \%$ ethanol, 70 to $100 \%$ isopropanol, the combination of $45 \%$ isopropanol with $30 \%$ n-propyl alcohol, 0.5 to $2.5 \%$ glutaraldehyde, 0.23 to $7.5 \%$ betadine, and 0.7 to $1 \%$ formic aldehyde have the ability to inactivate the coronavirus by approximately $4 \log 10$ or more [57]. Eggers et al. studied the use of povidone-iodine as a disinfectant for epidermis and body tissues against a wide range of microbes and viruses. Their study showed that povidone-iodine at a concentration of $1 \%$ or less can deactivate SARS-CoV in suspension by penetrating its membrane and attacking the 
proteins at sulfuryl and disulfide bonds [58-60].

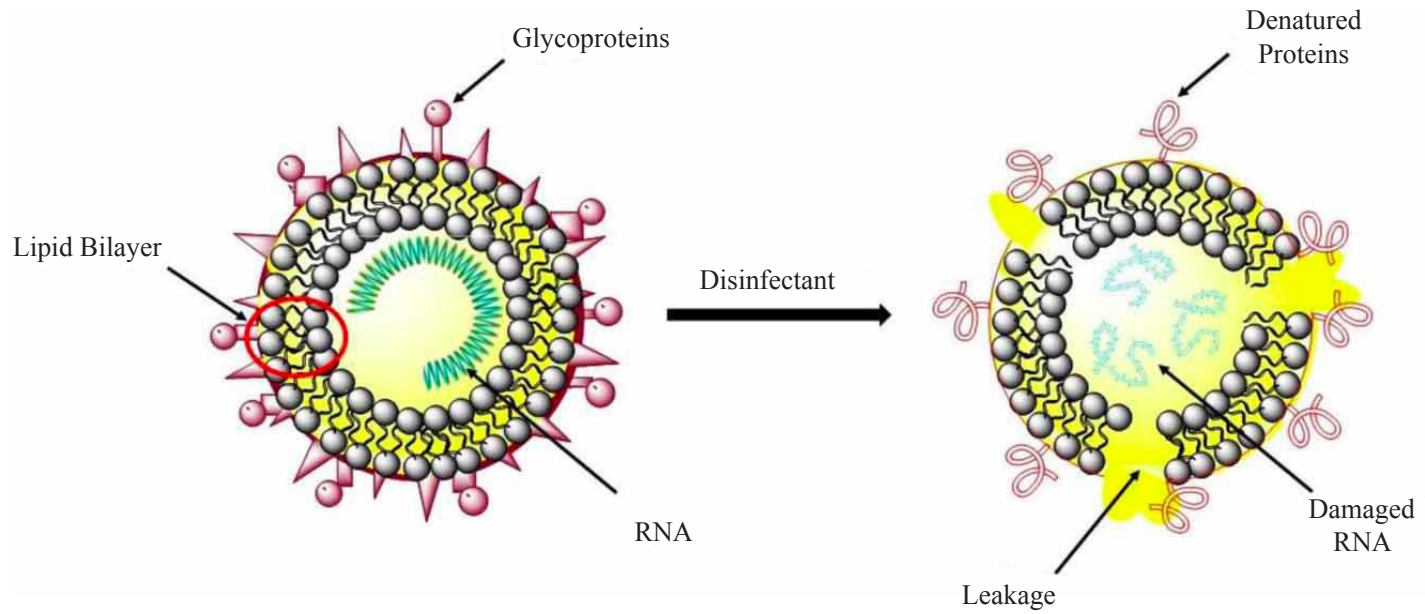

Figure 4. Schematic representation of the effect of disinfectant on coronavirus, Figure only reprinted from ref. [54], Copyrights IWA Publications

\subsection{Hand sanitizers}

In general, alcohols demonstrate a broad spectrum of germicidal activity against bacteria, fungi, and virus. Figure 5 represents the antiviral mechanism of alcohol against the enveloped virus. Isopropanol is potent against bacteria and ethanol is more active against the virus [61]. SARS-CoV-2 is a lipophilic enveloped virus and is more susceptible to isopropanol than ethanol, as isopropanol is more lipophilic [62-64]. Anindya et al. examined the virucidal activity of WHO-approved two alcohol-based formulations against Zika Virus (ZIKV), Ebola Virus (EBOV), SARS-CoV, MERS$\mathrm{CoV}$, and other enveloped viruses. It is observed that with a 30 second exposure time in a suspension test, both WHOapproved formulations showed viricidal activity against ZIKV, EBOV, and emerging CoV. Amongst the tested viruses, SARS-CoV was the most susceptible to WHO-approved alcohol-based formulation based on their inactivation analysis [65]. Anikka et al. verified diverse intensities of the native and revised WHO preparations, 2-propyl alcohol, and ethyl alcohol to study its virucidal activity against SARS-CoV-2. They found that both native and revised preparations of WHO, 2-propyl alcohol, and ethyl alcohol (concentration ${ }^{3} 30 \% \mathrm{v} / \mathrm{v}$ ) stood competent in disabling the virus within thirty seconds [66]. Thus, the COVID-19 virus which is hereditarily parallel to the SARS-CoV can also be inactivated with the different commercially available hand sanitizers. Table 4 details the advantages and disadvantages of both alcoholfree and alcohol-based hand sanitizers.

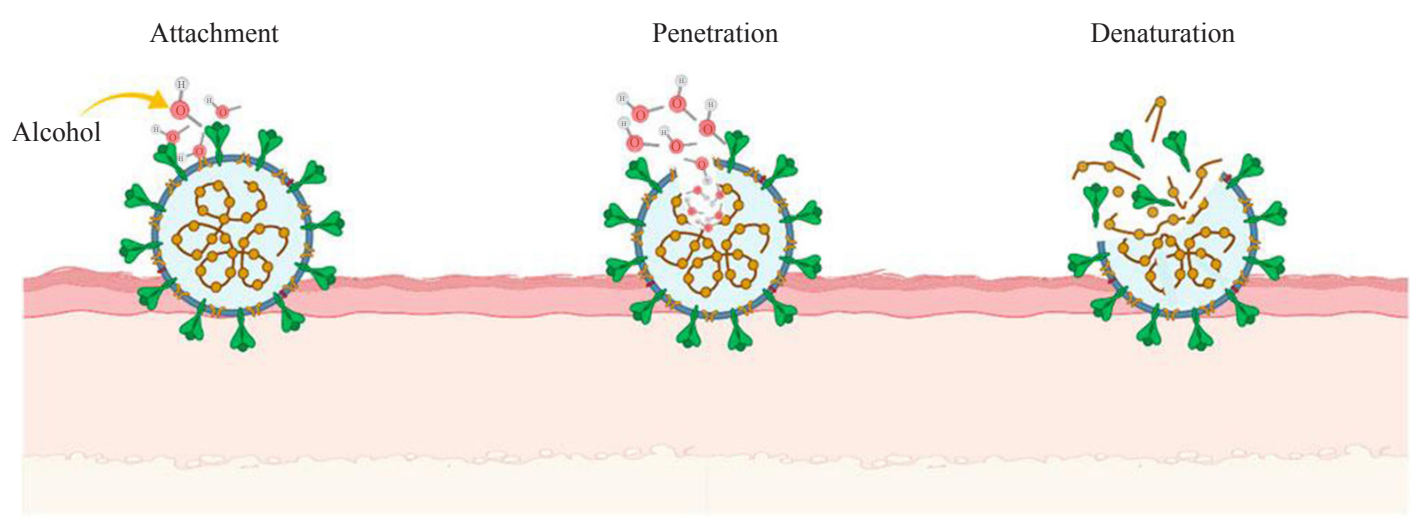

Figure 5. Antiviral mechanism of alcohol against enveloped virus, Figure only reprinted from ref. [61], Copyrights Cambridge University Publications 
Table 4. Types of hand sanitizers (Based on ref. [67])

\begin{tabular}{ccc}
\hline Types & Active Ingredient & Advantages \\
\hline $\begin{array}{c}\text { Alcohol-free hand } \\
\text { sanitizers }\end{array}$ & Benzalkonium chloride & $\begin{array}{c}\text { Reduced irritation, } \\
\text { less troublesome about } \\
\text { combustibility and misuse potential }\end{array}$ \\
$\begin{array}{c}\text { Alcohol-based } \\
\text { hand sanitizers }\end{array}$ & $\begin{array}{c}\text { Isopropanol, n-propyl alcohol, ethyl alcohol or their } \\
\text { mixture with humectants (avoid skin dryness) and } \\
\text { diluents (balance the artifact and delay the vaporization } \\
\text { of alcohol, thus escalating its sanitizing activity) }\end{array}$ & Low cost, efficacy \\
\hline
\end{tabular}

Tuladhar and the group stated that soap and water are better than alcohol-based hand disinfectants, as there was a significant reduction in infectivity when cleaning palms using soap and liquid than using hand disinfectants. Their study was on noroviruses and was observed that washing with soap and water for 30 seconds will completely remove genomic copies of the noroviruses [68]. But when scrubbing hands with soap is inaccessible or inopportune, an adequate measure of sanitizer is necessary to assure a thorough hand cleansing, for appropriate hygiene [67].

Table 5. Common PPEs and their materials (Based ref. [69], with actualization and addition)

\begin{tabular}{|c|c|c|c|c|}
\hline PPE & Purpose & Modules & Materials-properties & References \\
\hline \multirow{3}{*}{ Face shield } & \multirow{3}{*}{$\begin{array}{l}\text { Shields from the } \\
\text { droplets of contagious } \\
\text { body liquids concealing } \\
\text { oculus, nostrils } \\
\text { and oral cavity }\end{array}$} & Forehead band & Lightweight plastic & \multirow{3}{*}{ [70] } \\
\hline & & Transparent shield & $\begin{array}{l}\text { Lexan, tenite, polychloroethene-significantly } \\
\text { resilient to heat and chemicals } \\
\text { and decent visual value }\end{array}$ & \\
\hline & & Headband strap & Elastic materials-stretchable & \\
\hline \multirow{3}{*}{ Surgical mask } & \multirow{3}{*}{$\begin{array}{l}\text { To construct a } \\
\text { substantial block amid } \\
\text { the nostrils and oral } \\
\text { cavity of the user and } \\
\text { the infectious agent }\end{array}$} & Fabric layers & $\begin{array}{l}\text { Inner layer-hydrophilic spunbond fabrics } \\
\text { Middle layer-filter (removes pathogens) } \\
\text { Outer layer-hydrophobic nonwoven } \\
\text { fabrics like polypropene }\end{array}$ & \multirow{3}{*}{ [71] } \\
\hline & & Elastic band & Spandex, nylon, rayon-stretchable & \\
\hline & & Nose strip & Aluminium, plastic, non-woven-soft and malleable & \\
\hline \multirow[t]{3}{*}{$\begin{array}{l}\mathrm{N} 95 \\
\text { filtering respirator }\end{array}$} & \multirow[t]{3}{*}{$\begin{array}{l}\text { Safeguard the users } \\
\text { from contact to } \\
\text { aerial threats }\end{array}$} & Fabric layers & $\begin{array}{l}\text { Inner layer-hydrophilic spunbond fabrics } \\
\text { Second layer-melt-blown filter } \\
\text { (removes pathogens) } \\
\text { Third layer-made of paper/polyethylene terephthalate } \\
\text { Outer layer-hydrophobic nonwoven } \\
\text { fabrics like polypropene }\end{array}$ & \multirow[t]{3}{*}[72,73]{} \\
\hline & & Elastic band & Spandex, nylon, rayon-stretchable & \\
\hline & & Nose strip & Aluminium, plastic, non-woven-soft and malleable & \\
\hline Gloves & $\begin{array}{l}\text { Offers safety to hands } \\
\text { and avoid straight } \\
\text { interaction with } \\
\text { contagious means }\end{array}$ & & $\begin{array}{l}\text { Latex, nitrile rubber, } \\
\text { polyvinyl chloride and neoprene } \\
\text { (powdered and unpowdered)-flexible, } \\
\text { stretchable and resilient to tear }\end{array}$ & [74] \\
\hline Safety shoes & $\begin{array}{l}\text { Guards foot form } \\
\text { damage }\end{array}$ & Inner sole & $\begin{array}{l}\text { Melt-blown plastics like lexan, polypropene, } \\
\text { nylon-durable and strong }\end{array}$ & {$[75]$} \\
\hline \multirow[b]{2}{*}{ Isolation gown } & \multirow{2}{*}{$\begin{array}{l}\text { Protects patient care } \\
\text { assistants from } \\
\text { communicable vehicles }\end{array}$} & Reusable robe & $\begin{array}{l}\text { Dense-weight cotton, cotton blend fabrics-soft, } \\
\text { comfortable and relaxed }\end{array}$ & \multirow[b]{2}{*}{ [76] } \\
\hline & & Dispensable gown & $\begin{array}{l}\text { Polythene, polypropene, synthetic polymer } \\
\text { polyethylene terephthalate-significantly resilient to } \\
\text { heat, mechanical factors and chemicals }\end{array}$ & \\
\hline
\end{tabular}




\subsection{Personal protective equipment (PPE)}

The practice of an effective PPE is necessary to avoid the exponential spread of COVID-19. The various PPE being used are discussed in Table 5.

\subsubsection{Additive manufacturing}

Also called 3D printing; fabricates 3D objects by discharging the substance in a sequence of continuous thin deposits. This lithography system initiates from a 3D computer graphics prototype of the desired portion; which is then converted to a polyhedral representation in file types OBJ, AMF, or STL. This folder is provided to an operating system (slicer) and based on the parameters provided by the user; it segments the document case into sequences of tiers and saves them in a filing cabinet (G-code). The printer follows the saved instructions in G-code and shapes the segment by the addition of substance 1 tier at a while. Once printing is accomplished, the operator can perform the transforming procedures on the printed material. Based on this mode of operation there are different types of 3D printers and are now used as a resource for delivering supplementary PPEs [69]. Face masks have become an essential part of our life today. And during the initial time of the pandemic, most of the countries were facing a shortage in the availability of face masks [77]. This was later resolved using the help of 3D printing where the technology was utilized in developing PPEs, medical equipment, and other tools required for personal hygiene [78].

Table 6. Different drugs used for COVID-19 treatments (Based on ref. [79], with actualization \& addition)

\begin{tabular}{|c|c|c|c|c|c|c|}
\hline Drugs & Drug classification & Mechanism of action & Adult measure & Withholding factors & Detrimental effects & References \\
\hline $\begin{array}{l}\text { Choloroquine/ } \\
\text { Hydroxy- } \\
\text { Choloroquine } \\
\text { (CQ/HCQ) }\end{array}$ & $\begin{array}{c}\text { Class } 4 \text {-aminoquinoline; } \\
\text { works against } \\
\text { malarial parasites }\end{array}$ & $\begin{array}{l}\text { Restrict viral admission } \\
\& \text { departure within cell } \\
\text { and interrupt viral amino } \\
\text { acid chain production }\end{array}$ & $\begin{array}{l}\text { Oral, HCQ } 400 \mathrm{mg} \\
\text { (twice a day) for } 1 \text { day, } \\
\text { then } 400 \mathrm{mg} \text { for } \\
4 \text { days ( } 5 \text { doses) }\end{array}$ & $\begin{array}{l}\text { Known } \\
\text { hypersensitivity to } \\
\text { drug, existence of } \\
\text { defective field } \\
\text { of vision }\end{array}$ & $\begin{array}{l}\text { Limited } \\
\text { therapeutic ratio, } \\
\text { myelosuppression, } \\
\text { convulsion, affects } \\
\text { retina, muscle } \\
\text { weakness }\end{array}$ & {$[80,81]$} \\
\hline Remdesivir & $\begin{array}{l}\text { Nucleotide analogs; } \\
\text { antiviral drug }\end{array}$ & $\begin{array}{l}\text { Adenosine counterpart; } \\
\text { early expiry of the } \\
\text { budding viral RNA } \\
\text { chains by encompassing } \\
\text { viral genetic data }\end{array}$ & $\begin{array}{l}\mathrm{IV}, 200 \mathrm{mg} \text { for } 1 \text { day, } \\
\text { then } 100 \mathrm{mg} \\
\text { daily for } 9 \text { days } \\
\text { (10 doses) }\end{array}$ & & $\begin{array}{l}\text { Prominent level of } \\
\text { transaminases, } \\
\text { kidney injury }\end{array}$ & {$[82,83]$} \\
\hline Azithromycin & $\begin{array}{l}\text { Macrolide antibiotics; } \\
\text { works by stopping } \\
\text { the growth of bacteria }\end{array}$ & $\begin{array}{l}\text { Hinder bacterial } \\
\text { biomolecule production } \\
\text { and act against virus }\end{array}$ & $\begin{array}{l}\text { Oral, } 500 \mathrm{mg} \text { for } 1 \text { day, } \\
\text { then } 250 \mathrm{mg} \text { for } 4 \text { days } \\
\text { ( } 5 \text { days total })\end{array}$ & $\begin{array}{c}\text { Myasthenia gravis, } \\
\text { hypokalemia, } \\
\text { hypomagnesemia }\end{array}$ & $\begin{array}{l}\text { QT interval } \\
\text { prolongation }\end{array}$ & {$[81,84]$} \\
\hline Tocilizumab & $\begin{array}{l}\text { Interleukin-6 (IL-6) } \\
\text { obstructor; inhibits IL-6 }\end{array}$ & $\begin{array}{l}\text { Chimeric human IL-6 } \\
\text { monoclonal antibody; } \\
\text { binds to IL-6 receptors }\end{array}$ & $\begin{array}{l}\mathrm{IV}, 400 \mathrm{mg} \text { (flat dose) } \\
\text { for } 1 \text { day }\end{array}$ & $\begin{array}{l}\text { Known } \\
\text { hypersensitivity to } \\
\text { drug, alert sufferer } \\
\text { with neutropenia } \\
\text { or } \\
\text { thrombocytopenia }\end{array}$ & $\begin{array}{c}\text { Tuberculosis, } \\
\text { rhinitis, hypertension, } \\
\text { hematologic effects, } \\
\text { hepatotoxicity, } \\
\text { GIT perforation, } \\
\text { hypersensitivity } \\
\text { reactions }\end{array}$ & {$[85,86]$} \\
\hline Ribavirin & $\begin{array}{l}\text { Nucleoside analogues; } \\
\text { works by stopping } \\
\text { the spread of hepatitis } \\
\mathrm{C} \text { virus within the body }\end{array}$ & $\begin{array}{l}\text { Nucleoside counterpart } \\
\text { of guanosine, impede } \\
\text { RNA polymerase, } \\
\text { integrate with genetic } \\
\text { material triggering } \\
\text { alterations ensuing } \\
\text { faulty offspring }\end{array}$ & $\begin{array}{l}\text { Oral, } 400 \mathrm{mg} 3 \text { times } \\
\text { a day }(>50 \mathrm{ml} / \mathrm{min}) \\
400 \mathrm{mg} \text { twice a day } \\
(50-30 \mathrm{ml} / \mathrm{min}) \\
200 \mathrm{mg} \text { daily } \\
(<30 \mathrm{ml} / \mathrm{min}) \\
\text { for } 10 \text { days }\end{array}$ & $\begin{array}{l}\text { Expectant mother } \\
\text { and their spouse, } \\
\text { sufferer with } \\
\text { hemoglobinopathies }\end{array}$ & $\begin{array}{l}\text { Hemolytic anemia, } \\
\text { teratogenic }\end{array}$ & {$[87,88]$} \\
\hline $\begin{array}{l}\text { Lopinavir/ } \\
\text { Ritonavir }\end{array}$ & $\begin{array}{l}\text { Protease inhibitors; } \\
\text { used for treating } \\
\text { HIV infection }\end{array}$ & $\begin{array}{l}\text { Prevents HIV type } 1 \\
\text { protease (HIV-1) by } \\
\text { terminating growth of } \\
\text { HIV-1 and transmission; } \\
\text { analogous for } \\
\text { COVID-19 virus }\end{array}$ & $\begin{array}{l}\text { Oral, } 400 / 100 \mathrm{mg} \\
\text { (twice a day) } \\
\text { for } 10 \text { days }\end{array}$ & & $\begin{array}{l}\text { Common: gut } \\
\text { intolerance, vomiting } \\
\text { Major: Pancreatitis, } \\
\text { hepatotoxicity, } \\
\text { cardiac conduction } \\
\text { abnormality }\end{array}$ & {$[82,89]$} \\
\hline Favipiravir & $\begin{array}{l}\text { Modified pyrazine } \\
\text { analog; used for } \\
\text { treatment of } \\
\text { influenza virus }\end{array}$ & $\begin{array}{l}\text { Impedes RNA-dependent } \\
\text { RNA polymerase } \\
\text { (RdRp) affecting } \\
\text { chain annihilation }\end{array}$ & $\begin{array}{c}\text { Oral, measure differs } \\
\text { depending on } \\
\text { nephritic and } \\
\text { hepatic disorders }\end{array}$ & & $\begin{array}{c}\text { Neutropenia, } \\
\text { Diarrhea, } \\
\text { Hyperuricemia, } \\
\text { Elevated level } \\
\text { of transaminase }\end{array}$ & {$[90,91]$} \\
\hline
\end{tabular}




\section{Medicines}

The treatment possibilities available for COVID-19 are briefly discussed in Table 6 .

A study was done on 5 FDA standard drugs (nitazoxanide, chloroquine, nafamostat, penciclovir, and ribavirin) and 2 far-ranging medicines which eradicate or inactivate a virus (favipiravir and remdesivir) to evaluate its antiviral efficiency against a clinical isolate of COVID-19 virus. The laboratory study indicates the performance of remdesivir at a phase followed by virus admittance that agrees to its antiviral mechanism as a nucleotide analogue and effectively showed its antiviral efficiency in a human cell line [92]. A case report was testified by Xuhan and his group, in which they successfully treated a patient who has a history of multiple myeloma with tocilizumab against COVID-19. The patient aged 60-years was hospitalized for chest tightness without any fever or cough. Based on the CT imaging and the nucleic acid test results, he was diagnosed with severe COVID-19. He was given some antiviral tablets (arbidol) as a treatment method but later his chest tightness intensified with shortness of breath. He was then administered with tocilizumab for around 12 days, which cured him of the infection [93]. Based on the studies and the case reports, it is observed that the favorable medical care possibilities presented for COVID-19 positive cases with minor and relative symptoms are remdesivir and $\mathrm{HCQ} / \mathrm{CQ}$, and those with severe infection is tocilizumab [79]. As mentioned in Table 6, HCQ has several side effects which can be even fatal for some patients who have some existing conditions [94]. So, doctors have to be very careful while deciding the dose of this medicine for treating the COVID-19 patients.

\section{Vaccines}

Table 7. Different vaccines for COVID-19 (Based on refs. [95, 96])

\begin{tabular}{|c|c|c|c|c|c|}
\hline Types & Name & Technology & Mechanism & Dose & Storage \\
\hline \multirow{2}{*}{$\begin{array}{c}\text { mRNA } \\
\text { vaccines }\end{array}$} & Pfizer-BioNtech & $\begin{array}{l}\text { mRNA encapsulated with } \\
\text { lipid nanoparticle }\end{array}$ & $\begin{array}{l}\text { Makes harmless protein } \\
\text { unique to virus; destroys } \\
\text { the genetic material in } \\
\text { vaccine; body recognizes }\end{array}$ & $\begin{array}{l}2 \text { rounds within } \\
\text { a period of } 21 \text { days }\end{array}$ & $\begin{array}{l}\text { Freezer storage at } \\
-70^{\circ} \mathrm{C}, 5 \text { days } \\
\text { with refrigeration }\end{array}$ \\
\hline & Moderna & $\begin{array}{l}\text { mRNA encapsulated with } \\
\text { lipid nanoparticle }\end{array}$ & $\begin{array}{l}\text { the protein as foreign } \\
\text { and activates the immune } \\
\text { system generating } \\
\text { memory cells for the virus }\end{array}$ & $\begin{array}{l}2 \text { rounds within } \\
\text { a period of } 28 \text { days }\end{array}$ & $\begin{array}{l}6 \text { months at }-20^{\circ} \mathrm{C} \\
30 \text { days with } \\
\text { refrigeration }\end{array}$ \\
\hline $\begin{array}{l}\text { Protein } \\
\text { subunit } \\
\text { vaccines }\end{array}$ & NVX-CoV2373 & $\begin{array}{l}\text { Recombinant nano-scale } \\
\text { particle machinery to } \\
\text { produce antigen originated } \\
\text { from S polypeptide } \\
\text { of coronavirus }\end{array}$ & $\begin{array}{l}\text { Immune system } \\
\text { recognizes the protein } \\
\text { as foreign and removes } \\
\text { it by producing memory } \\
\text { cells for future infection }\end{array}$ & $\begin{array}{l}2 \text { doses, } 21 \text { days apart } \\
\text { (Phase } 3 \text { clinical trial) }\end{array}$ & $\begin{array}{l}\text { Refrigerated at } \\
2^{\circ} \mathrm{C} \text { to } 8^{\circ} \mathrm{C}\end{array}$ \\
\hline \multirow{2}{*}{$\begin{array}{l}\text { Inactivated } \\
\text { vaccines }\end{array}$} & Sinopharm & $\begin{array}{c}\text { Pathogen virus } \\
\text { inactivated by chemicals } \\
\text { or radiation }\end{array}$ & $\begin{array}{l}\text { Immune system } \\
\text { recognizes the antigens }\end{array}$ & $\begin{array}{l}2 \text { doses, } 3 \text { weeks apart } \\
\text { (Phase } 3 \text { trials ongoing) }\end{array}$ & $\begin{array}{l}\text { Refrigerated at } \\
2^{\circ} \mathrm{C} \text { to } 8^{\circ} \mathrm{C}\end{array}$ \\
\hline & Covaxin & $\begin{array}{l}\text { Pathogen virus is drenched in } \\
\text { beta-propiolactone to deactivate } \\
\text { only its genetic material }\end{array}$ & $\begin{array}{l}\text { when introduced } \\
\text { into the body }\end{array}$ & 2 doses, 28 days apart & Store at $2^{\circ} \mathrm{C}$ to $8^{\circ} \mathrm{C}$ \\
\hline \multirow{3}{*}{$\begin{array}{c}\text { Vector } \\
\text { vaccines }\end{array}$} & Oxfrord-AstraZeneca & & & 2 doses, 4 weeks apart & $\begin{array}{l}\text { Refrigerated at } \\
2^{\circ} \mathrm{C} \text { to } 8^{\circ} \mathrm{C}\end{array}$ \\
\hline & Johnson \& Johnson & $\begin{array}{l}\text { Contains weakened virus } \\
\text { (viral vectors), with genes } \\
\text { of } 2 \text { spike proteins }\end{array}$ & $\begin{array}{l}\text { Genetic material in viral } \\
\text { vectors makes protein, } \\
\text { there by activating } \\
\text { immune system }\end{array}$ & $\begin{array}{l}1 \text { and } 2 \text { dose schemes } \\
\text { are being tested } \\
\text { (Phase } 3 \text { trial data to be } \\
\text { released soon) }\end{array}$ & $\begin{array}{c}2 \text { years frozen at }-20^{\circ} \mathrm{C}, \\
3 \text { months refrigerated } \\
\text { at } 2^{\circ} \mathrm{C} \text { to } 8^{\circ} \mathrm{C}\end{array}$ \\
\hline & Gamaleya & & & $\begin{array}{l}2 \text { doses, } 3 \text { weeks apart } \\
\text { (Phase } 3 \text { trials ongoing) }\end{array}$ & Freezer storage at $-20^{\circ} \mathrm{C}$ \\
\hline
\end{tabular}


A vaccine is necessary to get control over the pandemic situation rather than treating it with medicines. This has made an urge in developing new effective vaccines against SARS-CoV-2 within a short span of time. Currently, there are many vaccines that are under clinical trials that have been developed in the fight against COVID-19. One of the main problems faced by many countries is the availability of the approved vaccines to the public free of cost. The working principle of vaccines is similar to how our body reacts to an infection. Different vaccines work in different ways to offer defense to the body. The different types of vaccines for COVID-19 are discussed in Table 7.

The assessment of the effectiveness of the vaccines, which is reported as the Relative Risk Reduction (RRR), is based on the results of the Phase III clinical trials of the vaccines which compare the frequency of the occurrence of COVID-19 disease in both immunized and unimmunized people. It is also said that we cannot predict the best vaccine for COVID-19 as each vaccine works differently by initiating a distinct form of immunity in different people [97]. Olliaro et al. reported the efficacy of Pfizer-BioNtech, Moderna, Oxford-AstraZeneca, Gamaleya, Johnson \& Johnson based on the observations proclaimed in scientific publications. They stated the highest efficacy for Pfizer-BioNtech (95\%), followed by Moderna (94\%), Gamaleya (91\%), and 67\% for Oxford-AstraZeneca and Johnson \& Johnson. The relative risk reduction was calculated by considering only the populations who benefited from the vaccine, so in order to calculate the effectiveness of the vaccine, we should also consider the absolute risk reduction which is calculated by considering both vaccinated and non-vaccinated populations. The absolute risk reduction was higher for OxfordAstraZeneca (1.3\%), followed by Moderna (1.2\%), Johnson \& Johnson (1.2\%), Gamaleya ( $0.93 \%)$, and Pfizer-BioNtech $(0.84 \%)$ [98]. Another group studied the safety and efficacy of the BNT162b2 mRNA vaccine candidate (Pfizer-BioNtech) and observed about $95 \%$ efficacy. They considered 43,448 candidates with an age of 16 years and above. Among them, half were injected with the mRNA vaccine, and half were injected with the placebo. They observed that, after 7 days, the second dose was taken; there were 8 cases among the vaccine injected candidates and 162 cases among the placebo injected candidates who had the onset of COVID-19 showing a 95\% efficacy of the vaccine. They also found an efficacy range of $90 \%$ to $100 \%$ in candidates depending on their age, existing disease conditions, sex, body mass index, etc. A safety median of 2 months was obtained for the BNT162b2 mRNA vaccine which was similar to other viral immunization [99]. Thus, the efficacy of a vaccine also depends on the physical condition of the candidates to whom it is injected.

\section{Medical devices}

For assuring the protection and productiveness of the different medical devices that are clinically available, FDA has classified it into Class I, II, or III, on the authority of the measure of risk management. Different medical devices are used at different stages of the infection and it is described in the Table below (Table 8).

The vital medical devices that are used during the COVID-19 pandemic include diagnostic test kits, ventilators, and PPE. There are many diagnostic test kits available for the detection of the pandemic and all these kits depend on the basic principle ELISA and PCR procedure. The medical devices that are included in the diagnostic kits are RTPCR, RT-LAMP, real-time RT-PCR, CT scanner, and swabs to obtain patient samples. Next are the ventilators which are now very important for COVID-19 patients to assist breathing and these are found in the intensive care units (ICU)s. A proper understanding of the working of ventilators is required as any mistake in the working can lead to lung failure. Another important medical device that plays as a barrier between the pathogen and the mouth, eyes, nose, and skin is the PPEs. These are a necessity for the healthcare workers who are working under such infectious conditions [69, 100]. The different devices that come under PPE are detailed in the below Table (Table 8). Other than the above-mentioned medical devices some other consumables and disposables are required during the COVID-19 fight and all these are detailed in Table 8. 
Table 8. List of medical devices and their classification in the context of COVID-19 (Based on refs. [101-103])

\begin{tabular}{|c|c|c|c|}
\hline Types & Medical devices & Stage of application & Classification \\
\hline \multirow[t]{6}{*}{ Disposables } & Bags for medical waste & $\begin{array}{l}\text { Sampling \& diagnosis, early therapy } \\
\text { \& monitoring, treatment }\end{array}$ & \\
\hline & Paper/tissue & $\begin{array}{l}\text { Initial care, Sampling \& diagnosis, } \\
\text { early therapy \& monitoring, treatment }\end{array}$ & \\
\hline & Endotracheal tube & Treatment & Class II \\
\hline & Oxygen tube & Early therapy \& monitoring, treatment & \\
\hline & Oropharyngeal airway & Treatment & Class I \\
\hline & Sharps container & $\begin{array}{l}\text { Sampling \& diagnosis, early therapy } \\
\text { \& monitoring, treatment }\end{array}$ & \\
\hline \multirow[t]{7}{*}{ PPE } & Apron & $\begin{array}{l}\text { Initial care, Sampling \& diagnosis, } \\
\text { early therapy \& monitoring, treatment }\end{array}$ & Class I \\
\hline & Face shields & $\begin{array}{l}\text { Sampling \& diagnosis, early therapy \& } \\
\text { monitoring, treatment }\end{array}$ & Not classified \\
\hline & Gloves (sterile \& non-sterile) & $\begin{array}{l}\text { Initial care, Sampling \& diagnosis, } \\
\text { early therapy \& monitoring, treatment }\end{array}$ & $\begin{array}{c}\text { Sterile-Class II } \\
\text { Non-sterile-Class I }\end{array}$ \\
\hline & Protective goggles & $\begin{array}{l}\text { Sampling \& diagnosis, early therapy } \\
\& \text { monitoring, treatment }\end{array}$ & \\
\hline & Gown & $\begin{array}{l}\text { Initial care, Sampling \& diagnosis, } \\
\text { early therapy \& monitoring, treatment }\end{array}$ & Class II \\
\hline & Medical mask & $\begin{array}{l}\text { Initial care, Sampling \& diagnosis, } \\
\text { early therapy \& monitoring, treatment }\end{array}$ & $\begin{array}{c}\text { Class I or II } \\
\text { Based on bacterial filtration efficiency }\end{array}$ \\
\hline & Respirator (N95/PPF2) & Treatment & Not classified \\
\hline \multirow[t]{10}{*}{ Medical Equipment } & Diagnosis kit (IVD) & Sampling \& Diagnosis & $\begin{array}{l}\text { Class I, II or III } \\
\text { Based on level of risk management for } \\
\text { certifying protection and productiveness }\end{array}$ \\
\hline & CT scanner & Treatment & Class II \\
\hline & $\begin{array}{l}\text { Cardiovascular ultrasound } \\
\text { imaging system }\end{array}$ & Treatment & Class II \\
\hline & Conventional X-ray equipment & $\begin{array}{l}\text { Initial care, early therapy } \\
\& \text { monitoring, treatment }\end{array}$ & Class I or II \\
\hline & Electrocardiogram & Early therapy \& monitoring, treatment & Class II \\
\hline & Portable suction system & Treatment & Class II \\
\hline & Portable ventilator & Early therapy \& monitoring, treatment & Class II \\
\hline & Portable ultrasound scanner & Treatment & $\begin{array}{c}\text { Class II or III } \\
\text { Based on application }\end{array}$ \\
\hline & Pulse oximeter & Early therapy \& monitoring, treatment & Class I \\
\hline & Vital signs monitor & Treatment & Class II \\
\hline Instrumental & Digital thermometer & Initial care, early therapy $\&$ monitoring & Class I \\
\hline \multirow[t]{3}{*}{ Solutions \& Reagents } & Alcohol-based hand rub & & Not classified \\
\hline & Chlorine-disinfectant & $\begin{array}{l}\text { Initial care, Sampling \& diagnosis, } \\
\text { early therapy \& monitoring, treatment }\end{array}$ & \\
\hline & Liquid soap & & \\
\hline
\end{tabular}




\section{Digital technologies}

Currently, everything is digitalized which initiates the study of various digital technologies in the field of COVID-19. Digital technologies are being exploited in public surveillance, contact tracing, case identification, and clinical care for improving the epidemiology of SARS-CoV-2. As smartphones possess reckoning potential, relativity, and accoutrements to simplify computerized recording; health-related databasing and point-of-care testing could be utilized to advance the pace and comfort of broadcasting, to cope with the expansion of an infectious disease [104]. To provide coordinated and controlled strategies by the national and global health agencies; smartphones could be accompanied by the preceding detection tests to offer an instantaneous geographical report. Generally, smartphones are used for contact tracing, which helps in tracking and identifying people who interact with positive cases and might be diseased; and these data can be digitized to deliver a complete and shareable record [105]. People can consult a doctor by not moving out of their habitat using telemedicine (implemented by many hospitals), a digital platform for clinical care [106]. Table 9 is describing the different digital technological skills that have been employed for COVID-19.

Table 9. Computerized skills for COVID-19 pandemic (Based on refs. [104, 106], with actualization \& addition)

\begin{tabular}{|c|c|c|c|c|}
\hline Hygienic Needs & Function & Digital Instrument & Illustration & References \\
\hline \multirow{3}{*}{$\begin{array}{l}\text { Electronic public-health } \\
\text { surveillance }\end{array}$} & \multirow{3}{*}{$\begin{array}{c}\text { Identification of } \\
\text { infection } \\
\text { and outburst reaction }\end{array}$} & Predictive analytics & $\begin{array}{l}\text { Online outbreak smart } \\
\text { appliances and internet-based } \\
\text { ailment examination }\end{array}$ & $\begin{array}{c}\text { Online intelligence tools: } \\
{[107-109]} \\
\text { Internet-based search data: } \\
{[110-112]}\end{array}$ \\
\hline & & Perlustrating apps \& databases & Recording the incidence of disease & [113-115] \\
\hline & & $\begin{array}{l}\text { Information withdrawal } \\
\text { and imagining }\end{array}$ & Data control panel & {$[116-118]$} \\
\hline \multirow{3}{*}{ Prompt case recognition } & \multirow{3}{*}{$\begin{array}{l}\text { Self and communal } \\
\text { testing, ailment } \\
\text { examination }\end{array}$} & Associated analytical method & Point-of-care identification & [119] \\
\hline & & $\begin{array}{l}\text { Instruments with } \\
\text { electronic accessories }\end{array}$ & Fever indicators & {$[120-122]$} \\
\hline & & Predictive analytics & Therapeutic image evaluation & {$[123,124]$} \\
\hline \multirow{2}{*}{$\begin{array}{l}\text { Intrusion of communal } \\
\text { diffusion }\end{array}$} & \multirow{2}{*}{$\begin{array}{l}\text { Self-isolation, association } \\
\text { to medical maintenance, } \\
\text { persistent contagion } \\
\text { scrutinizing }\end{array}$} & $\begin{array}{l}\text { Handheld platforms, } \\
\text { energy-efficient surfing } \\
\text { machinery }\end{array}$ & Integral contact reporting & $\begin{array}{c}\text { Paper: }[125] \\
\text { Apps: }[126-128] \\
\text { Frameworks: }[129-131]\end{array}$ \\
\hline & & Whereabouts of the cell phone & Motility-design enquiry & $\begin{array}{l}\text { Analysis: [132-134] } \\
\text { Datasets: [135-137] }\end{array}$ \\
\hline \multirow{3}{*}{ Communal interaction } & \multirow{3}{*}{$\begin{array}{l}\text { Hot spot documentation, } \\
\text { outbreak regulator }\end{array}$} & Social network podiums & Pointed interaction & {$[138,139]$} \\
\hline & & Web-based hunt devices & Highlighted evidence & {$[140]$} \\
\hline & & Interactive agents & Adapted material & {$[141]$} \\
\hline Medical precaution & $\begin{array}{l}\text { Identification of infected } \\
\text { and susceptible patients }\end{array}$ & Phone meeting & Appointment, e-health & {$[142]$} \\
\hline
\end{tabular}

Human aptitude combined computer schemes or Artificial Intelligence (AI), is an emerging method of working, which is used in clinical research (imaging platform- enabled with X-ray and CT [143]; clinical assessment and diagnosis-Symptoma, a symptom-to-disease digital health assistant [144]). Yang et al. developed a novel concept of empowering CT scanning with intelligence. They designed United imaging Human Automatic Planbox for PulmonarY 
(U-HAPPY) computer-assisted tomography surveying, with this they realized the face profile by acknowledging adjoining jawline via tutoring and evaluating the proposal network region on 76,882 faces of individuals employing a 2-D camera. A success rate of $98.7 \%$ (error distance of RPN $4.46 \pm 0.02$ pixels) in the training set and $100 \%$ (error distance of RPN $2.23 \pm 0.10$ pixels) in the testing set was obtained. Thus, this scanning technique makes a precise project administration to balance the required position and zone for scrutinizing and also reduces the radiation exposure significantly [145]. Health company Novant Health in partnership with Zipline developed drones (fly up 80 miles/hour) for delivering PPEs and other COVID supplies for a contactless experience. A software AirView is used in ventilation devices and CPAP machines that will collect the data and send it to the healthcare workers through a cloud and allows monitoring the patients staying at home. TytoCare is developing a special stethoscope that can transmit images of lungs and also listen to the patients. The hospitals have adopted virtual reality training to train their healthcare workers by keeping them safe and distanced. To reduce in-person interactions, hospitals are utilizing robots (e.g. Moxi) to deliver COVID relief. These are some of the healthcare innovations used during this pandemic period [146]. Accordingly, more strategies should be examined for the modulation and assessment of programmed tools, to reinforce the public in preparing and managing a pandemic situation in the future.

\section{Biomaterial applications}

The outbreak of COVID-19 has given the opportunity to involve multidisciplinary research areas to play different roles in the detection of infection and its management. Biomedical research is a key player, where different biomaterials are being engineered and their role in COVID-19 detection and regulation is being studied. One such biomaterial is the nanoparticles which show antiviral activity due to their distinctive physicochemical properties. These properties include larger surface area due to the smaller size, target-specific delivery, and stimulus sensitivity. Metal nanoparticles are good candidates as antiviral agents and polymeric nanoparticles can be exploited as drug carriers [147]. There are several other biomedical applications of modified nanomaterials which include optical imaging, photothermal imaging, biosensing, nanomedicines for cancer treatments, therapeutic agent delivery, photodynamic therapy, nanocarriers, and theranostics [148-152]. This will be a brief introduction to the various biomaterials that could be considered in the diagnosis and nursing measures of COVID-19 contagion.

\subsection{Diagnostics}

The initial step in the nucleic acid test or any other COVID-19 diagnostic test is the sample collection. The sample collection is done using the nasopharyngeal swabs. The shortage of these swabs made clinicians design and test their swabs. USF Health and Northwell Health in collaboration with Formlabs developed a prototype in which they are producing nasal swabs using 3D printers and with a biocompatible and autoclavable resin. These 3D printed nasal swabs were tested and they performed as well as the traditional nasal swabs [153].

Conventional RT-PCR technique has limitations leading to the improvement of health diagnostics that permits the patients to trial at the instance and place of nursing and the current research is based on these strategies to develop a brisk, explicit and simple analytical method with the incorporation of biomaterials. A group has developed an optical probe with gold nanoparticle-based surface plasmon resonance biosensors which change color depending on its size, shape, surface chemistry, and aggregation state [154, 155]. This probe can be utilized in molecular reactions to produce simple colorimetric readouts. Keith et al. reported a biomolecular platform that is rapid, acellular and lateral flow bands for revealing the Zika virus genome. They linked a toehold switch RNA sensor to the isothermal RNA amplification to detect the concentration of the Zika virus sequence. The specificity of this system was studied using a closely related Dengue viral sequence [156]. Table 10 is the list of different nanomaterial systems that are used in the lateral flow assay. A gold nanoisland-based plasmonic biosensor functionalized with complementary DNA receptors is built by Guangyu and his group to detect SARS-CoV-2 RNA. This biosensor exhibited a lower detection limit (0.22 pM) with specific and precise detection of the target [157]. Another group studied the sensitivity and specificity (IgG and IgM) of ELISA and an emulsion of the gold-immunochromatographic assay for screening SARS-CoV-2. The antigen is immobilized to the particle surface and when the test is put on the assay strip the immunoglobulins will secure to the immunogen, developing a dark red line [158]. 
Table 10. List of nanomaterial system used in lateral flow assay (Based on ref. [159])

\begin{tabular}{ccc}
\hline Nanoparticle system & Biological recognition & References \\
\hline Gold Nanoparticles (AuNPs) & Antibody & {$[160]$} \\
& DNA & {$[161]$} \\
Carbon Nanoparticles (CNPs) & Aptamer & {$[162]$} \\
Carbon Nanotubes (CNTs) & Antibody & {$[163]$} \\
Quantum Dots (QDs) & DNA & {$[164]$} \\
& Antibody & {$[165]$} \\
Upconverting Nanoparticles (UCNPs) & Aptamer & {$[166]$} \\
& Antibody & {$[167]$} \\
Liposomes & DNA & {$[168]$} \\
& Antibody & {$[169]$} \\
Magnetic Nanoparticles (MNPs) & DNA & {$[170]$} \\
\hline
\end{tabular}

Recent innovations in biochemical characteristics and medicinal attitudes are achieved by combining nanotechnology with biology and medicine [172]. Nanoparticles [173] and quantum dots are lately employed for distinguishing particular genetic codes. Quantum Dots (QD) are core-shell semiconductor nanoparticles that exhibit a modification in their optical and electronic properties and display different colors based on their size with a single excitation wavelength [174]. Yeh et al. developed a novel binary category of QD-facilitated nanosensors for identifying distinct DNA segments. The illumination indications were discharged from the quantum dot-DNA-probe complex, which determined the presence of the target. Furthermore, they used this technique to measure the target biomolecule by analyzing the coincident events [175]. Cao et al. used gold nanoparticle probes that are labelled with oligomers and Raman-active pigments for DNA/RNA detection. A silver coating formed by the gold nanoparticles acts as surfacesensible simulation, augmenting Raman scattering for the color stamped fragments that are caught by the preferred sequence [176]. Another group designed and tested a nanocrystal-biomolecule (QD-protein) nanosensor assembly, in which the biologically compatible QDs act as fluorescence resonance energy-transfer donors in recognitionbased sensing [177]. Taton et al. did a study in which they labelled nanoparticle probes rather than a fluorophore to the oligonucleotide targets for the scanometric array detection of DNA. This method points to the identification of oligonucleotide targets without the requisite target amplification [178].

\subsection{PPE}

\subsubsection{Surface inactivation}

The human-to-human viral transmission is from the aerosol particles and the cough droplets from an infected person. These droplets containing viruses can be on different surfaces and these viruses can remain active on the surfaces. So, it is necessary to disinfect the surfaces which are susceptible to contamination. The surfaces could be coated with different antiviral agents (metal catalysts-oxides/ions, nanomaterials with definite physical or chemical properties, macromolecules with recurrent components, etc.) to inactivate the virus [179]. Silver is renowned for its comprehensive range of microbicidal action, which tips to the use of silver nanoparticles in diverse biomedical applications [180]. In a study, the capability of silver nanoparticles to kill/inactivate the virus was analyzed opposite to the HIV-1 virus. The observed result is that silver nanoparticles $(1-10 \mathrm{~nm})$ were able to inactivate the virus by binding 
to sulfur-carrying deposits on the virus enfolding and thereby obstructing the viral attachment to the host cell [181]. It is studied by Tsuneo that copper oxides can disarm both enclosed and non-enclosed viruses with RNA/DNA as the genetic material by actively damaging the virus complexes [182]. Table 11 shows the list of nanoparticles that have antiviral activity and can be employed for the inactivation of various pathogens.

Table 11. List of nanoparticles with antiviral activity (Based on ref. [183])

\begin{tabular}{|c|c|c|c|}
\hline Nanoparticles & Properties & Uses & References \\
\hline Silver Nanoparticles (AgNPs) & $\begin{array}{l}\text { Physiochemical properties and } \\
\text { superior biological functions }\end{array}$ & $\begin{array}{l}\text { Used as instruments to kill or } \\
\text { prevent virus, fungus and bacteria, } \\
\text { counteracts cancer, reduces } \\
\text { inflammation, prevents platelet } \\
\text { agglomeration and impedes } \\
\text { maturity of new arteries }\end{array}$ & [184] \\
\hline AuNPs & $\begin{array}{l}\text { Exceptional electrical, optical, } \\
\text { mechanical and biological properties }\end{array}$ & $\begin{array}{l}\text { Cancer studies, antibacterial } \\
\text { and antiviral agent }\end{array}$ & {$[185]$} \\
\hline QDs & $\begin{array}{l}\text { Size-dependent optical and electronic } \\
\text { properties }\end{array}$ & $\begin{array}{l}\text { Limited use as antiviral agent, } \\
\text { cell labelling, detection } \\
\text { and image tracking }\end{array}$ & [186] \\
\hline Graphene Oxide (GO) & $\begin{array}{l}\text { Remarkable electronic, thermal and } \\
\text { mechanical properties }\end{array}$ & $\begin{array}{l}\text { Antibacterial, anticancer } \\
\text { and antiviral agent }\end{array}$ & {$[187]$} \\
\hline Zinc Oxide (ZO) & & Antimicrobial and antiviral agent & [188] \\
\hline Organic Nanoparticles & $\begin{array}{c}\text { Biocompatible, biodegradable and easy } \\
\text { surface modification }\end{array}$ & Antiviral agent and drug carrier & {$[189]$} \\
\hline
\end{tabular}

Surfactants are the functional element in domestic disinfectants and it has a virucidal influence. These surface operating vehicles can be incorporated into polymeric paints to put in an application on exteriors to stop the extent of disease-causing infection. There are chemical surfactants and biosurfactants, of which biosurfactant is less toxic and not influenced by the ambient aspects like $\mathrm{pH}$, heat, etc. [155]. The antiviral activity of biosurfactant (surfactin) on different enveloped viruses was studied and it was observed that the membrane active surfactants when interacted with the lipid membrane of the virus cause a viral disintegration [190].

\subsubsection{Viral filtration}

Tiliket and his colleagues reformed the mask tiers to improve the affinity to trap the airborne influenza virus A and the modification was done by chemically incorporating spun-bond polysaccharide fibril mesh into a market available protective mask [191]. In a study, the aerosolized bacteriophage MS2 was filtered using the influence of corona dispensed electrically charged particles. The charged particles are a result of the carbon thread ionizers which will charge the virus in the form of aerosol particles and when passed through the filter, the virus will be captured [192].

\subsection{Antiviral therapies}

Drug delivery system which is a widely used technique in cancer treatment can be exploited in the context of COVID-19 for the targeted delivery of the medicines. Different polymeric particles have been fabricated from universally used artificial resins with ester units, to show the local delivery of immunosuppressants and antibacterial therapeutics. Tyrospheres are prefabricated tyrosine-extracted macromolecular nanospheres used in cancer treatments to lessen the lethal reactions and also to retain medicinal chemistry [193]. Another nanomaterial strategy is to design nanodecoys-a nanostructure developed to mimic living cells. Rao et al. developed a nanodecoy of gelatin nanoparticles in mosquito-derived cell membranes to capture the Zika virus [155]. Auranofin is a WHO categorized gold composites 
employed in medicine and was investigated on SARS-CoV-2 by Rothan et al. and found that at low micromolar concentrations of the drug, it hindered 50\% reproduction of COVID-19 virus and also abridged the formulation of SARS-CoV-2 stimulated biological responses in Huh7 cells [194]. This suggests auranofin can be used to control the SARS-CoV-2 epidemic and its accompanying lung damage. Nanomaterials can be redesigned with antibodies to enhance drug application by shrinking side effects and also co-delivered with angiogenesis factors to generate better antiviral drug delivery [195]. Recently studies are showing that vitamin E is not just a vitamin supplement for COVID-19 treatment but it acts as an anti-ferroptosis drug that can reduce the damage to the tissues due to infections and thereby minimize the mortality rate. The COVID-19 patients are having a varying RBC volume which is associated with the change in the level of iron serum. This can lead to ferroptosis, a programmed cell death indicated by lipid peroxides and depending on the iron level in the body. Current clinical studies revealed that vitamin $\mathrm{E}$ has the potential to inhibit ferroptosis and can be exploited as an anti-ferroptosis drug [196].

\subsection{Vaccines}

To develop an efficient vaccine that can be used clinically, there is a requirement for the selection of a potent antigen, an adjuvant, and a delivery vehicle. Nanomaterials have significantly gained notice as a possible adjuvant and carrier. There are nanoparticles, microneedles, scaffolds, and liposomes that are being used as biomaterial-based solutions for vaccine development. Eun Kim and his colleagues evolved a vaccine, formulated on a hydrocarbon microneedle assembly for MERS, by means of S protein protomer of the virus as an agglutinogen and observed a promising response in mice. Later a similar microneedle vaccine was developed for COVID-19, exploiting a SARS$\mathrm{CoV}-2 \mathrm{~S}$ protein protomer as the antigen and obtained a persistent antigen-distinct immunoglobulin response in the rodent [197]. For better immune activation and targeted vaccine delivery, the nanomaterials can be biologically engineered to incorporate antibodies that can be utilized for the development of new vaccine candidates in the near future [195].

\section{Organoid cultures}

In biology research the in vivo studies are done on animal models, sometimes which has limitations in addressing specific questions related to human biology; so, it is better to develop a human-based model, to understand the biological phenomena undertaking. Recently, this is possible with organoid cultures that are widely used by researchers to study infectious diseases, genetic disorders, and cancer [198]. Organoids are 3D structures enclosing differentiated cell kinds which are self-sustained to generate assemblies of the structural and functional unit. They are advanced from Induced Pluripotent progenitor/Stem Cells (iPSCs) or multipotent Adult progenitor/Stem Cells (ASCs). To develop an iPSCs-based organoid, the iPSCs are allowed to form a 3-dimensional collection of pluripotent cells and subsequently engaged within a progression that do an impression of the consecutive evolutionary pathways; while the ASCs-based organoid is established by taking the completely determined progenitor cells from the collection of cells that execute the definite function of interest and then raised in a specific combination of growth promoters that construct comprehensive organoid [199].

These systems are widely used in virology to study the mechanism of pathogenesis. During the Zika virus epidemic, a human cerebral organoid (mini-brains) was established from iPSCs, to understand the development of severe congenital abnormalities (microcephaly). A series of studies were done on the organoid and it was understood that in a developing brain, the Zika virus can replicate and infect and kill the neural precursors leading to microcephaly [200]. Youk et al. cultured a 3-dimensional replica of human alveolar progenitor cells to evaluate the infection response of the COVID-19 virus. The results were obtained from digital copy administering procedure and single-cell proteome streamlining, which revealed an improved illustration of interferon-related genetic material and proinflammatory genetic material in the alveolar stem cells revealing the replication of the virus and ensuring a natural resistance [201]. Another group established abdominal organoids copied from leaf-nosed bats of the Rhinolophidae family to demonstrate that SARS-CoV-2 can infect the bat gastric cells. Further, they developed a human intestinal organoid and studied the viral replication in the intestinal organoid suggesting that the human gastric tract is a way for the virus to convey [202]. There are other organoid models including brain organoids, liver organoids, tonsil organoids, kidney organoids, etc. to study 
the manner of development of SARS-CoV-2. The major problem with the organoid system is the lack of a combined immune system to understand the immune response to these contagious viruses. This headed to the elaboration of organ-on-chip models to study the immune responses to the infection. Organ-on-chip is a 3D human organotypic model consisting f a microfluidic device to culture the cells. Zhang et al. developed a human alveolar chip to study the lung injury and immune responses provoked by the infection of the COVID-19 virus. The results showed that after viral infection there was an activated innate immune response at the epithelium and activated cytokine-dependent routes at endothelium; providing new insight into the SARS-CoV-2 pathogenesis [203]. Thus, these techniques can be adapted by integrating varying features to practice in a pandemic stage, currently the COVID-19.

Table 12. List of emerging SARS-CoV-2 variants (Based on ref. [204-209])

\begin{tabular}{|c|c|c|c|c|c|}
\hline Variant & WHO label & Emerged country & Mutation & Impact & Other reported countries \\
\hline $\begin{array}{l}\text { B.1.1.7 lineage } \\
(\mathrm{GR} / 501 \mathrm{Y} . \mathrm{V} 1)\end{array}$ & Alpha & $\begin{array}{l}\text { United Kingdom } \\
\text { (UK) }\end{array}$ & $\begin{array}{l}\text { Mutation in the spike } \\
\text { protein-at Receptor Binding } \\
\text { Domain, asparagine }(\mathrm{N}) \\
\text { substituted with tyrosine }(\mathrm{Y}) \text {; } \\
69 / 70 \text { deletion-conformational } \\
\text { change in spike protein; } \\
\text { P681H-high variability }\end{array}$ & $\begin{array}{c}\text { Increased transmissibility } \\
\text { and increased risk } \\
\text { of death matched } \\
\text { with other mutants }\end{array}$ & $\begin{array}{c}\text { Since } 20 \text { December } 2020 \text {, } \\
\text { several countries } \\
\text { including United States } \\
\text { (US) }\end{array}$ \\
\hline $\begin{array}{l}\text { B.1.351 lineage } \\
(\mathrm{GH} / 501 \mathrm{Y} . \mathrm{V} 2)\end{array}$ & Beta & South Africa & $\begin{array}{l}\text { Multiple mutations in the spike } \\
\text { protein, including K417N, } \\
\text { E484K, N501Y }\end{array}$ & $\begin{array}{c}\text { Spike protein (E484K) } \\
\text { mutations may affect } \\
\text { neutralization by some } \\
\text { polyclonal and } \\
\text { monoclonal antibodies }\end{array}$ & $\begin{array}{l}\text { Zambia-late December } \\
\text { 2020, US-end of } \\
\text { January } 2021\end{array}$ \\
\hline $\begin{array}{l}\text { P.1 lineage } \\
\text { (GR/501Y.V3) }\end{array}$ & Gamma & Brazil & $\begin{array}{l}3 \text { mutations in spike protein } \\
\text { RBD: K417T, E484K, } \\
\text { and N501Y }\end{array}$ & $\begin{array}{l}\text { May affect transmissibility } \\
\text { and angiogenic profile } \\
\text { affecting the ability of } \\
\text { antibodies generated through } \\
\text { previous natural infection } \\
\text { or through vaccination } \\
\text { to recognize } \\
\text { and neutralize the virus }\end{array}$ & US-end of January 2021 \\
\hline $\begin{array}{l}\text { B.1.427 \& B.1.429 } \\
\text { (GH/452R.V1) }\end{array}$ & Epsilon & California & $\begin{array}{c}\text { B.1.427-mutation in spike } \\
\text { protein RBD: L452R; } \\
\text { B.1.429-5 mutations in spike } \\
\text { protein RBD: I4205V in orfla, } \\
\text { D1183Y in orflb: } \\
\text { S13I, W152C and L452R }\end{array}$ & $\begin{array}{l}\text { Easily transmissible and } \\
\text { lower the benefit of } \\
\text { antibodies initiated } \\
\text { by former infection } \\
\text { or by a vaccine }\end{array}$ & California-February 2021 \\
\hline $\begin{array}{c}\text { B.1.617.2 } \\
(\mathrm{G} / 478 \mathrm{~K} . \mathrm{V} 1)\end{array}$ & Delta & India & $\begin{array}{c}13 \text { mutations altering the } \\
\text { amino acid sequences, } \\
\text { in which } 4 \text { in the spike proteins } \\
\text { RBD: D614G, T478K, } \\
\text { L452R and P681R }\end{array}$ & $\begin{array}{l}\text { Increased transmissibility } \\
\text { and increased risk of death } \\
\text { matched with all other } \\
\text { mutants and may lower } \\
\text { the benefit of some } \\
\text { treatments and antibodies } \\
\text { initiated by a vaccine }\end{array}$ & US-March 2021 \\
\hline
\end{tabular}

\section{Variant strains}

The SARS-CoV-2 virus has been affecting social life for more than a year now and this has led to the change in its DNA sequence or simply mutation due to environmental factors and some other physiological factors. Viruses will continuously vary and become further diversified. These mutations have evolved these viruses to different variant strains which are more dangerous than the earlier strain in transmissibility and risk of death. Scientists have studied these mutations taking place in the virus and named the different strains of SARS-CoV-2. Table 12 is the list of various variant strains of SARS-CoV-2 which have been detected in various parts of the country.

The efficiency of various vaccines on these different variant strains of the pandemic virus was studied by the 
researchers to understand how efficient the developed vaccines are against the COVID-19 disease and in the future what all changes need to be done in the vaccine development. Emary and his group studied the reaction of the viral vector vaccine Oxford-AstraZeneca against the alpha lineage of the SARS-CoV-2 virus. To carry out the experiment, they considered volunteers who were part of the efficacy study and of age 18 years and above. Regular nucleic acid amplification tests were done on the swab samples and the positive samples were routinely sequenced to study its genomic features. The neutralizing antibody responses were also studied against the alpha lineage. They compared and observed that the efficacy of the vaccine against alpha variant and non-alpha variant are $42 \%-89 \%$ and $71 \%$ $91 \%$ respectively [210]. In another study, the Novavax vaccine which is reported to have $95.6 \%$ efficacy against the normal virus, also showed an efficacy of $85.6 \%$ against the alpha variant and $60 \%$ against the beta variant based on the preliminary clinical studies. They selected the volunteers between the age of 18 and 84 years with a $27 \%$ above the age of 65 years [211]. Some studies confirmed that the serum taken from the patients who were vaccinated using PfizerBioNtech and Moderna against the alpha and beta lineage showed a decrease in the antibody neutralizing activity; that the variants are antibody resistant [212]. A recent study by Hoffmann compared the alpha, beta, and gamma variants of the SARS-CoV-2 virus in patients who were vaccinated using the Pfizer-BioNtech vaccine. Their study showed that even though the inhibitors are effective in blocking the entry of the variants into the cell, the beta and gamma variants escape from the antibody response initiated by the previous infection or by the vaccine. They also showed that the beta and gamma variants are resistant to some of the antibody treatments [213]. Thus, more studies are necessary to understand the effect of the viral variants towards the current vaccines and also in the future to develop new vaccine candidates to completely rule over the pandemic.

\section{Future directions}

Since the end of 2019, COVID-19 has tremendously affected public health, life, and the economy. This had a catastrophic impact on the global economy due to the worldwide lockdown causing the fall of social well-being. Even though vaccination is started worldwide, it will take more time in containing COVID-19 completely. Social distancing and good hygienic practices are compulsory implementations that are required to delay the commencement of community transmission and reduce the frequency of the cases [214]. As a citizen of our country, it is our responsibility to realize and accept the significance of healthcare intervention measures like examination, quarantine of the diseased, contact report, preventive self-seclusion, etc. in dropping the number of cases [215]. It is very important to know the routes of transmission for the pandemic, so it is highly necessary to study the paths through which the disease is transmitted other than the human-to-human contact. There are environmental factors like temperature, humidity, and season that affected the outbreak of COVID-19 in many countries [216]. Reinfections of some of the recovered patients are also being reported, for which we require more evidence.

The developments and expansions in the field of science and research which include next-generation sequencing have made it easier for the early diagnosis and detection of the pandemic disease COVID-19. There is a collection of diagnostic tests that are available with much more accuracy, ease, and speed compared to conventional methods. But as the virus is getting mutated, all these test kits will require optimization to cope with the changes [18]. Recently researchers are incorporating nanoplatforms in the fight against COVID-19. There are nanoparticles that are being employed for diagnostic tests, drug delivery, vaccine development, etc. for curbing this epidemic situation. This can be further improved if we have a better understanding of how the nanoparticles interact with the pathogens and become lethal to the cells, designing nanoparticles with a better drug capturing capability and better biodistribution. Another important point that needs to be taken care of is the targeted drug delivery which can limit the delivery of drugs to the undesired tissues or organs [147]. Thus, making improvements and developments in the field of nanoscience can create more vehicles that can be used against the SARS-CoV-2 virus and thereby upgrading the current situation.

The outbreak of COVID-19 has made us closer to the digital world. Everything is digitalized now, from contact tracing, telemedicine, online learning to business deals. Digital technologies have to be stronger as this can be followed during a future pandemic situation [217]. Digital technology can be combined with diagnostic tools for having better control over the transmission of infection and consequently reducing the death rate. The availability of personal protective equipment for healthcare workers should not be compromised as they are more susceptible to infections 
[18]. The last matter of concern should always be, to be prepared for another wave of COVID-19 outbreak. In several countries, there was a second wave of infection, of which some countries are still struggling to get control over the virus. Currently, vaccines have been developed against SARS-CoV-2, but the worry is how efficient it will be against the mutant variants of the virus that is newly reported.

\section{Conclusion}

Even though many different diagnostic tests are clinically available, RT-PCR is the most accepted among them, as it is a more specific and rapid test. The flaw with this technique is the false-negative result and also requires expertise to perform the test. To overcome this limitation, we may incorporate a molecular tool like CRISPR with the isothermal amplification of the target DNA and then attaining the result on a lateral flow strip. The virus detection can be done using a simple machine utilizing ATP monitoring which measures the organic matter left on a surface after cleaning. Using a swab and luminometer, we can monitor the viral contamination thereby reducing the viral invasion in humans. The surface contamination can be removed by surface disinfectants that deactivate the lipid envelope. The other PPEs including the face mask, face shields, hand sanitizers, gloves, gowns, footwear are widely used by the auxiliary nurses and the population. This, to an extent, can prevent the infection. There are reports showing that washing your hand with soap and water is always better than using sanitizer. During the initial period of the viral outbreak, there was a shortage of the PPEs and this made the researchers utilize additive manufacturing/3D printing to produce PPEs. The infected people were hospitalized, isolated, and monitored regularly with X-rays and CT scans and were under medications. The studies indicate that remdesivir and tocilizumab remain as the favorable therapeutic possibilities of COVID-19. Recent medical advancements have made the development of vaccines within a short period. Currently, different vaccines are available in the market. And in most of the countries, they have started vaccination to wipe out the virus causing the pandemic. There are researches undergoing, with the implication of biomaterials for the establishment of various diagnostic methods, nanomedicines utilizing nanomaterials, quantum dots, microarrays, etc. One major advancement in COVID-19 is the use of organoid culture, which helps in understanding the pathogenesis of the virus and also the immune response against the virus. Another concern about SARS-CoV-2 is the emerging variant that has been lately reported in different countries. To get complete control over COVID-19, there has to be more analysis and studies taking place with the incorporation of multidisciplinary research areas. There are limitations for the recently available techniques and we hope that more advanced development of methodologies which are rapid and more specific, can help all of us to lead a normal life like before.

\section{Conflicts of interest}

The authors declare no conflict of interest.

\section{Acknowledgment}

This work was supported by the NUS COVID-19 Research Seed Funding with Reference No: NUSCOVID19RG-11.

\section{References}

[1] Peiris JSM, Guan Y, Yuen KY. Severe acute respiratory syndrome. Nature Medicine. 2004; 10: 88-97. Available from: http://www.nature.com/naturemedicine/ [Accessed 17th January 2021].

[2] Shereen MA, Khan S, Kazmi A, Bashir N, Siddique R. COVID-19 infection: Origin, transmission, and characteristics of human coronaviruses. Journal of Advanced Research. 2020; 24: 91-98. Available from: doi: 10.1016/j.jare.2020.03.005.

[3] Memish ZA, Zumla AI, Al-Hakeem RF, Al-Rabeeah AA, Stephens GM. Family cluster of middle east respiratory 
syndrome coronavirus infections. The New England Journal of Medicine. 2013; 26: 2487-2494.

[4] Wang C, Horby PW, Hayden FG, Gao GF. A novel coronavirus outbreak of global health concern. The Thelancet. 2020; 395: 470-473. Available from: https://doi.org/10.1016/S0140-6736(20)30185-9 [Accessed 17th January 2021].

[5] Lai CC, Shih TP, Ko WC, Tang HJ, Hsueh PR. Severe acute respiratory syndrome coronavirus 2 (SARSCoV-2) and coronavirus disease-2019 (COVID-19): The epidemic and the challenges. International Journal of Antimicrobial Agents. 2020; 55: 1-9. Available from: doi: 10.1016/j.ijantimicag.2020.105924.

[6] Hu T, Liu Y, Zhao M, Zhuang Q, Xu L, He Q. A comparison of COVID-19, SARS and MERS. PeerJ. 2020; 8: e9725. Available from: doi: 10.7717/peerj.9725.

[7] Hu B, Guo H, Zhou P, Shi ZL. Characteristics of SARS-CoV-2 and COVID-19. Nature Reviews Microbiology. 2020; 1-14. Available from: doi: 10.1038/s41579-020-00459-7.

[8] Boheemen SV, Graaf MD, Lauber C, Bestebroer TM, Raj VS, Zaki AM, et al. Genomic characterization of a newly discovered coronavirus associated with acute respiratory distress syndrome in humans. mBio. ASM. 2012; 3: 1-9. Available from: http://mbio.asm.org/content/3/6/e00473-12.full.html [Accessed 17th January 2021].

[9] Zu ZY, Jiang MD, Xu PP, Chen W, Ni QQ, Lu GM, et al. coronavirus disease 2019 (COVID-19): A perspective from China. Radiology. 2020; 296: 15-25. Available from: doi: 10.1148/radiol.2020200490.

[10] Huang C, Wang Y, Li X, Ren L, Zhao J, Hu Y, et al. Clinical features of patients infected with 2019 novel coronavirus in Wuhan, China. Lancet. 2020; 395: 497-506. Available from: https://doi.org/10.1016/S01406736(20)30183-5 [Accessed 31st January 2021].

[11] Wang D, Hu B, Hu C, Zhu F, Liu X, Zhang J, et al. Clinical characteristics of 138 hospitalized patients with 2019 novel coronavirus-infected pneumonia in Wuhan, China. The Journal of the American Medical Association. 2020; 323: 1061-1069. Available from: doi: 10.1001/jama.2020.1585.

[12] Panchal N, Kamal R, Orgera K, Cox C, Garfield R, Hamel L, et al. The implications of COVID-19 for mental health and substance use. KFF. 2020; 1-17. Available from: https://www.kff.org/coronavirus-covid-19/issue-brief/ the-implications-of-covid-19-for-mental-health-and-substance-use/ [Accessed 31st January 2021].

[13] Zietz M, Zucker J, Tatonetti NP. Associations between blood type and COVID-19 infection, intubation, and death. Nature Communications. 2020; 11: 1-6. Available from: doi: 10.1038/s41467-020-19623-x.

[14] Zhao J, Yang Y, Huang H, Li D, Gu D, Lu X, et al. Relationship between the ABO blood group and COVID-19 susceptibility. medRxiv. 2020; 1-18. Available from: https://doi.org/10.1101/2020.03.11.20031096 [Accessed 18th February 2021].

[15] Ellighaus D, Degenhardt F, Bujanda L, Buti M, Albillos A, Invernizzi P, et al. Genomewide association study of severe COVID-19 with respiratory failure. The New England Journal of Medicine. 2020; 383: 1522-1534. Available from: doi: 10.1056/NEJMoa2020283.

[16] Xie X, Zhong Z, Zhao W, Zheng C, Wang F, Liu J. Chest CT for typical coronavirus disease 2019 (COVID-19) pneumonia: Relationship to negative RT-PCR testing. Radiology. 2020; 296: 41-45. Available from: doi: 10.1148/ radiol.2020200343.

[17] Tan CW, Chia WN, Qin X, Liu P, Chen MIC, Tiu C, et al. A SARS-CoV-2 surrogate virus neutralization test based on antibody-mediated blockage of ACE2-spike protein-protein interaction. Nature Biotechnology. 2020; 38: 10731078. Available from: doi: 10.1038/s41587-020-0631-z.

[18] Mardian Y, Kosasih H, Karyana M, Neal A, Lau CY. Review of current COVID-19 diagnostics and opportunities for further development. Frontiers in Medicine (Lausanne). 2021; 8: 615099. Available from: doi: 10.3389/ fmed.2021.615099.

[19] Lia C, Zhao C, Bao J, Tang B, Wang Y, Gu B. Laboratory diagnosis of coronavirus disease-2019 (COVID-19). Clinica Chimica Acta. 2020; 510: 35-46. Available from: doi: 10.1016/j.cca.2020.06.045.

[20] Garg A, Ghoshal U, Patel SS, Sing DV, Arya AK, Vasanth S, et al. Evaluation of seven commercial RT-PCR kits for COVID-19 testing in pooled clinical specimens. Journal of Medical Virology. 2020; 1-6. Available from: doi: 10.1002/jmv.26691.

[21] Kasteren PV, Veer BVD, Wijsman L, Brink SVD, Jonge JD, Brandt AVD, et al. Comparison of commercial RTPCR diagnostic kits for COVID-19. National Institute of Public Health and the Environment. 2020; 1-9. Available from: doi: 10.1016/j.jev.2020.104412.

[22] Li Q, Guan X, Wu P, Wang X, Zhou L, Tong Y, et al. Early transmission dynamics in Wuhan, China, of novel coronavirus-infected pneumonia. The New England Journal of Medicine. 2020; 382(13): 1199-1207. Available from: doi: 10.1056/NEJMoa2001316.

[23] Corman VM, Landt O, Kaiser M, Molenkamp R, Meijer A, Chu DK, et al. Detection of 2019 novel coronavirus 
(2019-nCoV) by real-time RT-PCR. Euro Surveillance: Bulletin Europeen sur les Maladies Transmissibles $=$ European Communicable Disease Bulletin. 2020; 25(3): 2000045. Available from: https://doi.org/10.2807/15607917.ES.2020.25.3.2000045 [Accessed 26th January 2021].

[24] Suo T, Liu X, Feng J, Guo M, Hu W, Guo D, et al. ddPCR: A more accurate tool for SARS-CoV-2 detection in low viral load specimens. Emerging Microbes \& Infections. 2020; 9(1): 1259-1268. Available from: doi: 10.1080/22221751.2020.1772678.

[25] Wang J, Cai K, Zhang R, He X, Shen X, Liu J, et al. Novel one-step single-tube nested quantitative real-time PCR assay for highly sensitive detection of SARS-CoV-2. Analytical Chemistry. 2020; 92(13): 9399-9404. Available from: doi: 10.1021/acs.analchem.0c01884.

[26] Zhang Y, Odiwuor N, Xiong J, Sun L, Nyaruaba RO, Wei H, et al. Rapid molecular detection of SARSCoV-2 (COVID-19) virus RNA using colorimetric LAMP. medRxiv. 2020; 1-14. Available from: https://doi. org/10.1101/2020.02.26.20028373 [Accessed 26th January 2021].

[27] Hogan CA, Sahoo MK, Huang C, Garamani N, Stevens B, Zehnder J, et al. Five-minute point-of-care testing for SARS-CoV-2: Not there yet. Journal of Clinical Viroogyl. 2020; 128: 104410. Available from: doi: 10.1016/ j.jcv.2020.104410.

[28] Zhen W, Smith E, Manji R, Schron D, Berry GJ. Clinical evaluation of three sample-to-answer platforms for detection of SARS-CoV-2. Journal of Clinical Microbiology. 2020; 58(8): e00783-20. Available from: doi: 10.1128/JCM.00783-20.

[29] Zhao Z, Cui H, Song W, Ru X, Zhou W, Yu X. A simple magnetic nanoparticles-based viral RNA extraction method for efficient detection of SARS-CoV-2. bioRxiv. 2020; 1-18. Available from: https://doi. org/10.1101/2020.02.22.961268 [Accessed 26th January 2021].

[30] Zhu X, Wang, X, Han L, Chen T, Wang L, Li H, et al. Reverse transcription loop-mediated isothermal amplification combined with nanoparticles-based biosensor for diagnosis of COVID-19. medRxiv. 2020; 1-19. Available from: https://doi.org/10.1101/2020.03.17.20037796 [Accessed 26th January 2021].

[31] AccessBio, CareStart ${ }^{\mathrm{TM}}$. Rapid diagnostic test for the detection of SARS-CoV-2 antigen. 2020. Available from: https://store-nxo5xr56.mybigcommerce.com/content/pdf/IFU-RCHM71-E\%20\%28E\%29\%20IFU\%202021-0415F.pdf [Accessed 18th January 2021].

[32] Diao B, Wen K, Chen J, Liu Y, Yuan Z, Han C, et al. Diagnosis of acute respiratory syndrome coronavirus 2 infection by detection of nucleocapsid protein. medRxiv preprint. 2020; 1-13. Available from: https://doi. org/10.1101/2020.03.07.20032524 [Accessed 25th January 2021].

[33] Kohmer N, Westhaus S, Ruhi C, Ciesek S, Rabenau HF. Clinical performance of SARS-1 CoV-2 IgG antibody tests and potential protective immunity. bioRxiv preprint. 2020; 1-14. Available from: https://doi. org/10.1101/2020.05.08.085506 [Accessed 25th January 2021].

[34] Liu W, Liu L, Kou G, Zheng Y, Ding Y, Ni W, et al. Evaluation of nucleocapsid and spike protein-based enzymelinked immunosorbent assays for detecting antibodies againstSARS-CoV-2. Journal of Clinical Microbiology. 2020; 58(6): 1-25. Available from: doi: 10.1128/JCM.00461-20.

[35] Pérez-García F, Pérez-Tanoira R, Romanyk J, Arroyo T, Gómez-Herruz P, Cuadros-González J. Alltest rapid lateral flow immunoassays is reliable in diagnosing SARS-CoV-2 infection from 14 days after symptom onset: A prospective single-center study. Journal of Clinical Virology. 2020; 129: 104473. Available from: doi: 10.1016/ j.jcv.2020.104473.

[36] Hedde PN, Abram TJ, Jain A, Nakajima R, de Assis RR, Pearce T, et al. A modular microarray maging system for highly specific COVID-19 antibody testing. Lab on a Chip. 2020; 20: 3302-3309. Available from: doi: 10.1039/ d01c00547a.

[37] Kohmer N, Westhaus S, Ruhl C, Ciesek S, Rabenau HF. Clinical performance of SARS-CoV-2 IgG antibody tests and potential protective immunity. bioRxiv. 2020; 1-15. Available from: https://doi.org/10.1101/2020.05.08.085506 [Accessed 26th January 2021].

[38] Cai XF, Chen J, Li Hu J, Long QX, Deng HJ, Liu P, et al. A peptide-based magnetic chemiluminescence enzyme immunoassay for serological diagnosis of coronavirus disease 2019 (COVID-19). The Journal of Infectious Diseases. 2020; 222(2):189-193. Available from: doi: 10.1093/infdis/jiaa243.

[39] Lu R, Zhao X, Li J, Niu P, Yang B, Wu H, et al. Genomic characterisation and epidemiology of 2019 novel coronavirus: Implications for virus origins and receptot. Thelancet. 2020; 1-10. Available from: https://doi. org/10.1016/S0140-6736(20)30251-8 [Accessed 25th January 2021].

[40] Chen L, Liu W, Zhang Q, Xu K, Ye G, Wu W, et al. RNA based mNGS approach identifies a novel human coronavirus from two individual pneumonia cases in 2019 Wuhan outbreak. Emerging Microbes and Infections. 
2020; 9(1): 313-319. Available from: doi: 10.1080/22221751.2020.1725399.

[41] Lu R, Zhao X, Li J, Niu P, Yang B, Wu H, et al. Genomic characterisation and epidemiology of 2019 novel coronavirus: implications for virus origins and receptor binding. Lancet. 2020; 395(10224): 565-574. Available from: doi: 10.1016/S0140-6736(20)30251-8.

[42] Xiao M, Liu X, Ji J, Li M, Li J, Yang L, et al. Multiple approaches for massively parallel sequencing of HCoV19 (SARS-CoV-2) genomes directly from clinical samples. bioRxiv. 2020; 1-25. Available from: https://doi. org/10.1101/2020.03.16.993584 [Accessed 28th January 2021].

[43] Wang M, Fu A, Hu B, Tong Y, Liu R, Liu Z, et al. Nanopore targeted sequencing for the accurate and comprehensive detection of SARS-CoV-2 and other respiratory viruses. Small. 2020; 16(32): e2002169. Available from: doi: 10.1002/smll.202002169.

[44] Chen JS, Ma E, Harrington LB, Costa MD, Tian X, Palefsky JM, et al. CRISPR-Cas12a target binding unleashes indiscriminate single-stranded DNase activity. Science. 2018; 360: 436-439.

[45] Cox DBT, Gootenberg JS, Abudayyeh OO, Franklin B, Kellner MJ, Joung J, et al. RNA editing with CRISPRCas13. Science. 2017; 358: 1019-1027.

[46] Feng W, Newbigging AM, Le C, Pang B, Peng H, Cao Y, et al. Molecular diagnosis of COVID-19: Challenges and research needs. Analytical Chemistry. 2020; 92: 10196-10209. Available from: doi: 10.1021/acs.analchem.0c02060.

[47] Broughton JP, Deng X, Yu G, Fasching CL, Servellita V, Sing J, et al. CRISPR-Cas12-based detection of SARSCoV-2. Nature Biotechnology. 2020; 38: 870-874. Available from: doi: 10.1038/s41587-020-0513-4.

[48] Lillis K. ATP testing: A proven method to measure cleanliness. 2015. p. 5-7. Available from: https://www.hygiena. com/wp-content/uploads/2020/09/ATP-Testing-A-Proven-Method-to-Measure-Cleanliness.pdf [Accessed 16th January 2021].

[49] Havics AAT. A look at COVID 19 in terms of: 9. Using ATP \& the Mycometer ${ }^{\circledR}$ for assessing cleaning completeness. Technical Report. 2020; 1-8. Available from: doi: 10.13140/RG.2.2.24131.14884.

[50] Sifuentes LY, Fankem SLM, Reynolds K, Tamimi AH, Gerba CP, Koenig D. Use of ATP readings to predict a successful hygiene intervention in the workplace to reduce the spread of viruses on fomite. Food and Environmental Virology. 2016; 1-7. Available from: doi: 10.1007/s12560-016-9256-2.

[51] Mahmood A, Eqan M, Pervez S, Alghamdi HA, Tabinda AB, Yasar A, et al. COVID-19 and frequent use of hand sanitizers; human health and environmental hazards by exposure pathways. Science of the Total Environment. 2020; 742: 140561. Available from: doi: 10.1016/j.scitotenv.2020.140561.

[52] Pradhan D, Biswasroy P, Naik PK, Ghosh G, Rath G. A review of current interventions for COVID-19 prevention. Archives of Medical Research. 2020; 51: 363-374. Available from: doi: 10.1016/j.arcmed.2020.04.020.

[53] Addie DD, Baralon CB, Egberink H, Frymus T, Jones TG, Hartmann K, et al. Disinfectant choices in veterinary practices, shelters and households ABCD guidelines on safe and effective disinfection for feline environments. Journal of Feline Medicine and Surgery. 2015; 17: 594-605. Available from: doi: 10.1177/1098612X15588450.

[54] Al-Sayah MH. Chemical disinfectants of COVID-19: An overview. Journal of Water and Health. 2020; 18: 843848. Available from: doi: 10.2166/wh.2020.108.

[55] Rabenau HF, Kampf G, Cinatl J, Doerr HW. Efficacy of various disinfectants against SARS coronavirus. Journal of Hospital Infection. 2005; 61: 107-111. Available from: doi: 10.1016/j.jhin.2004.12.023.

[56] Rabenau HF, Cintal J, Morgenstern B, Bauer G, Preiser W, Doerr HW. Stability and inactivation of SARS coronavirus. Medical Microbiology and Immunology. 2005; 194: 1-6. Available from: doi: 10.1007/s00430-0040219-0.

[57] Kampf G. Potential role of inanimate surfaces for the spread of coronaviruses and their inactivation with disinfectant agents. Infection Prevention in Practice. 2020; 2: 1-2. Available from: doi: 10.1016/ j.infpip.2020.100044.

[58] Eggers M, Eickmann M, Zorn J. Rapid and effective virucidal activity of povidone-iodine products against middle east respiratory syndrome coronavirus (MERS-CoV) and modified vaccinia virus ankara (MVA). Infectious Diseases and Therapy. 2015; 4: 491-501. Available from: doi: 10.1007/s40121-015-0091-9.

[59] Eggers M, Janssen TK, Ward LS, Newby C, Muller S. Bactericidal and virucidal activity of povidone-iodine and chlorhexidine gluconate cleansers in an In Vivo hand hygiene clinical simulation study. Infectious Diseases and Therapy. 2018; 7: 235-247. Available from: doi: 10.1007/s40121-018-0202-5.

[60] Eggers M, Janssen TK, Eickmann M, Zorn J. In vitro bactericidal and virucidal efficacy of povidone-iodine gargle/ mouthwash against respiratory and oral tract pathogens. Infectious Diseases and Therapy. 2018; 7: $249-259$. Available from: doi: 10.1007/s40121-018-0200-7.

[61] Singh D, Joshi K, Samuel A, Patra J, Mahindroo N. Alcohol-based hand sanitisers as first line of defence against 
SARS-CoV-2: A review of biology, chemistry and formulations. Epidemiology and Infection. 2020; 148 : 1-9. Available from: doi: 10.1017/S0950268820002319.

[62] Schoeman D, Fielding BC. Coronavirus envelope protein: Current knowledge. Virology Journal. 2019 ; 16 : 1-22. Available from: doi: 10.1186/s12985-019-1182-0.

[63] Ionidis G, Hubscher J, Jack T, Becker B, Bischoff B, Todt D, et al. Development and virucidal activity of a novel alcohol-based hand disinfectant supplemented with urea and citric acid. BMC Infectious Diseases. 2016; 16: 14101419. Available from: doi: 10.1186/s12879-016-1410-9.

[64] Wu Q, Zhang Y, Lu H, Wang J, He X, Liu Y, et al. The E protein is a multifunctional membrane protein of SARSCoV. Genomics, Proteomics and Bioinformatics. 2003; 1(2): 131-144. Available from: doi: 10.1016/s16720229(03)01017-9.

[65] Siddharta A, Pfaender S, Vielle NJ, Dijkman R, Friesland M, Becker B, et al. Virucidal activity of WHOrecommended formulations against enveloped viruses including Zika, Ebola and emerging Coronaviruses. Journal of Infectious Diseases. 2017; 215: 1-18. Available from: doi: 10.1093/infdis/jix046.

[66] Kratzel A, Todt D, V'Kovski P, Steiner S, Gultom M, Thao TTN, et al. Inactivation of severe acute respiratory syndrome coronavirus 2 by WHO-recommended hand rub formulations and alcohols. Emerging Infectious Diseases. 2020; 26(7): 1592-1595. Available from: doi: 10.3201/eid2607.200915.

[67] Golin AP, Choi D, Ghahary A. Hand sanitizers: A review of ingredients, mechanisms of action, modes of delivery, and efficacy against coronaviruses. American Journal of Infection Control. 2020; 48: 1062-1067. Available from: doi: 10.1016/j.ajic.2020.06.182.

[68] Tuladhar E, Hazeleger WC, Koopmans M, Zwietering MH, Duizer E, Beumer RR. Reducing viral contamination from finger pads: Handwashing is more effective than alcohol-based hand disinfectants. Journal of Hospital Infection. 2015; 90(3): 226-234. Available from: doi: 10.1016/j.jhin.2015.02.019.

[69] Advincula R, Dizon JRC, Chen Q, Niu I, Chung J, Kilpatrick L, et al. Additive manufacturing for COVID-19: devices, materials, prospects, and challenges. MRS Communications. 2020; 10(3): 413-427. Available from: doi: 10.1557/mrc.2020.57.

[70] Roberge RJ. Face shields for infection control: A review. Journal of Occupational and Environmental Hygiene. 2016; 13(4): 235-242. Available from: doi: 10.1080/15459624.2015.1095302.

[71] Henneberry B. How surgical masks are made. Thomas. Available from: https://www.thomasnet.com/articles/other/ how-surgical-masks-are-made/ [Accessed 4th February 2021].

[72] The National Academics of Sciences Engineering Medicine. Characteristics of respirators and medical masks. The National Academic Press; 2006. p. 22-41. Available from: https://www.nap.edu/read/11637/chapter/4 [Accessed 4th February 2021].

[73] Henneberry B. How to make N95 Masks. Thomas. Available from: https://www.thomasnet.com/articles/plantfacility-equipment/how-to-make-n95-masks/ [Accessed 6th February 2021].

[74] Devenish D. An overview of the 9 most common glove materials (and their pro's and con's). Badger. Available from: https://www.badgeraustralia.com.au/blog/an-overview-of-the-9-most-common-glove-materials-and-theirpros-cons/ [Accessed 6th February 2021].

[75] Irzmanska E, Brochocka A. Modified polymer materials for use in selected personal protective equipment products. AUTEX Research Journal. 2017; 17(1): 36-47.

[76] Thomas. How to make protective gowns for coronavirus/COVID-19. Available from: https://www.thomasnet.com/ articles/other/how-to-make-protective-gowns-for-coronavirus-covid-19/ [Accessed 5th February 2021].

[77] Ji D, Fan L, Li X, Ramakrishna S. Addressing the worldwide shortages of face masks. BMC Materials. 2020; 2(1): 1-11. Available from: doi: 10.1186/s42833-020-00015-w.

[78] Singh S, Prakash C, Ramakrishna S. Three-dimensional printing in the fight against novel virus COVID-19: Technology helping society during an infectious disease pandemic. Technology in Society. 2020; 62: 1-20. Available from: doi: 10.1016/j.techsoc.2020.101305.

[79] Ali MJ, Hanif M, Haider MA, Ahmed MU, Sundas FNU, Hirani A, et al. Treatment options for COVID-19: A review. Frontiers in Medicine. 2020; 7: 1-10. Available from: https://doi.org/10.3389/fmed.2020.00480 [Accessed 16th January 2021].

[80] Fantini J, Di Scala C, Chahinian H, Yahi N. Structural and molecular modelling studies reveal a new mechanism of action of chloroquine and hydroxychloroquine against SARS-CoV-2 infection. International Journal of Antimicrobial Agents. 2020; 55(5): 105960. Available from: doi: 10.1016/j.ijantimicag.2020.105960.

[81] Gautret P, Lagier JC, Parola P, Hoang VT, Meddeb L, Mailhe M, et al. Hydroxychloroquine and azithromycin as a treatment of COVID-19: Results of an open-label non-randomized clinical trial. International Journal of 
Antimicrobial Agents. 2020; 56(1): 105949. Available from: doi: 10.1016/j.ijantimicag.2020.105949.

[82] Choy KT, Wong AY, Kaewpreedee P, Sia SF, Chen D, Hui KPY, et al. Remdesivir, lopinavir, emetine, and homoharringtonine inhibit SARS-CoV-2 replication in vitro. Antiviral Research. 2020; 178: 104786. Available from: doi: 10.1016/j.antiviral.2020.104786.

[83] Beigel JH, Tomashek KM, Dodd LE, Mehta AK, Zingman BS, Kalil AC, et al. Remdesivir for the treatment of Covid-19-Final Report. The New England Journal of Medicine. 2020; 383(19): 1813-1826. Available from: doi: 10.1056/NEJMoa2007764.

[84] Ohe M, Shida H, Jodo S, Kusunoki Y, Seki M, Furuya K, et al. Macrolide treatment for COVID-19: Will this be the way forward? BioScience Trends. 2020; 14(2): 159-160. Available from: doi: 10.5582/bst.2020.03058.

[85] Zhang C, Wu Z, Li JW, Zhao H, Wang GQ. Cytokine release syndrome in severe COVID-19: Interleukin-6 receptor antagonist tocilizumab may be the key to reduce mortality. International Journal of Antimicrobial Agents. 2020; 55(5): 105954. Available from: doi: 10.1016/j.jjantimicag.2020.105954.

[86] Xu X, Han M, Li T, Sun W, Wang D, Fu B, et al. Effective treatment of severe COVID-19 patients with tocilizumab. Proceedings of the National Academy of Sciences of the United States of America. 2020; 117(20): 10970-10975. Available from: doi: 10.1073/pnas.2005615117.

[87] Elfiky AA. Ribavirin, remdesivir, sofosbuvir, galidesivir, and tenofovir against SARS-CoV-2 RNA dependent RNA polymerase (RdRp): A molecular docking study. Life Sciences. 2020; 253: 117592. Available from: doi: 10.1016/ j.lfs.2020.117592.

[88] Khalid M, Al Rabiah F, Khan B, Al Mobeireek A, Butt TS, Al Mutairy E. Ribavirin and interferon- $\alpha 2 b$ as primary and preventive treatment for Middle East respiratory syndrome coronavirus: A preliminary report of two cases. Antiviral Therapy. 2015; 20(1): 87-91. Available from: doi: 10.3851/IMP2792.

[89] Lim J, Jeon S, Shin HY, Kim MJ, Seong YM, Lee WJ, et al. Case of the index patient who caused tertiary transmission of COVID-19 infection in Korea: The application of lopinavir/ritonavir for the treatment of COVID-19 infected pneumonia monitored by quantitative RT-PCR. Journal of Korean Medical Science. 2020; 35(6): e79. Available from: doi: 10.3346/jkms.2020.35.e79.

[90] Chen C, Zhang Y, Huang J, Yin P, Cheng Z, Wu J, et al. Favipiravir versus arbidolfor COVID-19: A randomized clinical trial. medRxiv. 2020; 1-30. Available from: https://doi.org/10.1101/2020.03.17.20037432 [Accessed 26th January 2021].

[91] Du YX, Chen XP. Favipiravir: Pharmacokinetics and concerns about clinical trials for 2019-nCoV infection. Clinical Pharmacology and Therapeutics. 2020; 108(2): 242-247. Available from: doi: 10.1002/cpt.1844.

[92] Wang M, Cao R, Zhang L, Yang X, Liu J, Xu M, et al. Remdesivir and chloroquine effectively inhibit the recently emerged novel coronavirus (2019-nCoV) in vitro. Cell Research. 2020; 30(3): 269-271. Available from: doi: 10.1038/s41422-020-0282-0.

[93] Zhang X, Song K, Tong F, Fei M, Guo H, Lu Z, et al. First case of COVID-19 in a patient with multiple myeloma successfully treated with tocilizumab. Blood Advances. 2020; 4(7): 1307-1310. Available from: doi: 10.1182/ bloodadvances.2020001907.

[94] Alanagreh L, Alzoughool F, Atoum M. Risk of using hydroxychloroquine as a treatment of COVID-19. International Journal of Risk and Safety in Medicine. 2020; 31(3): 111-116. Available from: doi: 10.3233/JRS200024.

[95] Centers for Disease Control and Prevention (CDC). COVID-19, Understanding How COVID-19 Vaccines Work. 2021. Available from: https://www.cdc.gov/coronavirus/2019-ncov/vaccines/different-vaccines/how-they-work. html [Accessed 19th January 2021].

[96] Koirala A, Joo YJ, Khatami A, Chiu C, Britton PN. Vaccines for COVID-19: The current state of play. Paediatric Respiratory Reviews. 2020; 35: 43-49. Available from: doi: 10.1016/j.prrv.2020.06.010.

[97] Forni G, Mantovani A. COVID-19 vaccines: where we stand and challenges ahead. Cell Death and Differentiation. 2021; 28(2): 626-639. Available from: doi: 10.1038/s41418-020-00720-9.

[98] Olliaro P, Torreele E, Vaillant M. COVID-19 vaccine efficacy and effectiveness-the elephant (not) in the room. Lancet Microbe. 2021. Available from: doi: 10.1016/S2666-5247(21)00069-0 [Accessed 14th June 2021].

[99] Polack FP, Thomas SJ, Kitchin N, Absalon J, Gurtman A, Lockhart S, et al. Safety and efficacy of the BNT162b2 mRNA Covid-19 vaccine. The New England Journal of Medicine. 2020; 383(27): 2603-2615. Available from: doi: 10.1056/NEJMoa2034577.

[100]U.S. Food and Drug Administration (FDA). Medical devices and the COVID-19 (coronavirus) pandemic. Available from: https://www.fda.gov/medicaldevices/emergency-situations-medical-devices/medical-devices-andcovid-19coronavirus-pandemic [Accessed 14th June 2021]. 
[101]Pan American Health Organization-World Health Organization (PAHO). List of Priority Medical Devices in the Context of COVID-19. 2020. p. 2-4. Available from: https://iris.paho.org/bitstream/handle/10665.2/52580/ PAHOIMSHSSCOVID-19200030_eng.pdf?sequence=1\&isAllowed=y [Accessed 26th January 2021].

[102]U.S. Food and Drug Administration (FDA). Product Classification. Available from: https://www.accessdata.fda. gov/scripts/cdrh/cfdocs/cfpcd/classification.cfm [Accessed 28th January 2021].

[103]U.S. Food and Drug Administration (FDA). Overview of IVD Regulation. Available from: https://www.fda.gov/ medical-devices/ivd-regulatory-assistance/overview-ivd-regulation [Accessed 28th January 2021].

[104]Wood CS, Thomas MR, Budd J, Thompson TPM, Herbst K, Pillay D, et al. Taking connected mobile-health diagnostics of infectious diseases to the field. Nature. 2019; 566(7745): 467-474. Available from: doi: 10.1038/ s41586-019-0956-2.

[105]Udugama B, Kadhiresan P, Kazlowski HN, Malekjahani A, Osborne M, Li VYC, et al. Diagnosing COVID-19: The disease and tools for detection. ACS. Nano. 2020; 14: 3822-3835. Available from: doi: 10.1021/acsnano.0c02624.

[106]Budd J, Miller BS, Manning EM, Lampos V, Zhuang M, Edelstein M, et al. Digital technologies in the publichealth response to COVID-19. Nature Medicine. 2020; 26(8): 1183-1192. Available from: doi: 10.1038/s41591020-1011-4.

[107]HealthMap. COVID-19. Available from: https://www.healthmap.org/covid-19/ [Accessed 2nd February 2021].

[108]World Health Organization (WHO). Epidemic intelligence from open sources (EIOS). 2020. Available from: https://www.who.int/eios [Accessed 2nd February 2021].

[109]World Health Organization (WHO). EPI-BRAIN. 2020. Available from: https://www.epi-brain.com/ [Accessed 2nd February 2021].

[110]Qin 1, Sun Q, Wang Y, Wu KF, Chen M, Shia BC, et al. Prediction of number of cases of 2019 novel coronavirus (COVID-19) using social media search index. International Journal of Environmental Research and Public Health. 2020; 17(7): 1-14. Available from: doi: 10.3390/ijerph17072365.

[111]Lu Y, Zhang L. Social media WeChat infers the development trend of COVID-19. Journal of Infection. 2020; 81(1): 82-83. Available from: doi: 10.1016/j.jinf.2020.03.050.

[112]Lampos V, Majumder MS, Tov EY, Edelstein M, Moura S, Hamad Y, et al. Tracking COVID-19 using online search. NPJ Digital Medicine. 2021; 4(1): 17. Available from: https://arxiv.org/abs/2003.08086 [Accessed 2nd February 2021].

[113]COVID Near You. 2020. Available from: https://www.covidnearyou.org/ [Accessed 2nd February 2021].

[114]Menni C, Valdes AM, Freidin MB, Sudre CH, Nguyen LH, Drew DA, et al. Real-time tracking of self-reported symptoms to predict potential COVID-19. Nature Medicine. 2020; 26(7): 1037-1040. Available from: doi: 10.1038/ s41591-020-0916-2.

[115]Singapore COVID-19 Symptom Checker. 2020. Available from: https://sgcovidcheck.gov.sg/ [Accessed 2nd February 2021].

[116]Ministry of Health Singapore. Updates on COVID-19 (coronavirus disease 2019) local situation. 2020. Available from: https://www.moh.gov.sg/covid-19/ [Accessed 2nd February 2021].

[117]Nextstrain team. Genomic epidemiology of novel coronavirus-global subsampling. Available from: https:// nextstrain.org/ncov/global [Accessed 2nd February 2021].

[118]Covid19 SG. Dashboard of the COVID-19 virus outbreak in Singapore. Available from: https://co.vid19.sg/ singapore/dashboard [Accessed 1st February 2021].

[119]FIND. SARS-CoV-2 diagnostic pipeline. Available from: https://www.finddx.org/covid-19/pipeline/ [Accessed 2nd February 2021].

[120]Gostic K, Gomez ACR, Mummah RO, Kucharski AJ, Smith JOL. Estimated effectiveness of symptom and risk screening to prevent the spread of COVID-19. eLife. 2020; 9: 1-18. Available from: doi: 10.7554/eLife.55570.

[121]Quilty BJ, Clifford S, CMMID nCoV working group, Flasche S, Eggo RM. Effectiveness of airport screening at detecting travelers infected with novel coronavirus (2019-nCoV). Eurosurveillance. 2020; 25(5): 1-6. Available from: doi: 10.2807/1560-7917.ES.2020.25.5.2000080.

[122]Armitage, H. Stanford Medicine scientists hope to use data from wearable devices to predict illness, including COVID-19. Stanford Medicine News Center. 2020. Available from: http://med.stanford.edu/news/all-news/2020/04/ wearable-devices-for-predicting-illness-.html [Accessed 2nd February 2021].

[123]Mei X, Lee HC, Diao KY, Huang M, Lin B, Liu C, et al. Artificial intelligence-enabled rapid diagnosis of patients with COVID-19. Nature Medicine. 2020; 26: 1224-1228. Available from: doi: 10.1038/s41591-020-0931-3.

[124]Wang S, Kang B, Ma J, Zeng X, Xiao M, Guo J, et al. A deep learning algorithm using CT images to screen for corona virus disease. European Radiology. 2021; 1-9. Available from: doi: 10.1101/2020.02.14.20023028. 
[125]Fretti L, Wymant C, Kendall M, Zhao L, Nurtay A, Dorner LA, et al. Quantifying SARS-CoV-2 transmission suggests epidemic control with digital contact tracing. Science. 2020; 368(6491): 620-628. Available from: doi: 10.1126/science.abb6936.

[126]Ministry of Health. HaMagen-the Ministry of Health app for fighting the spread of coronavirus. 2020. Available from: https://govextra.gov.il/ministry-of-health/hamagen-app/download-en/ [Accessed 2nd February 2021].

[127]Australian Government Department of Health. COVIDSafe app. 2020. Available from: https://www.health.gov.au/ resources/apps-and-tools/covidsafe-app [Accessed 3rd February 2021].

[128]Government of India. Aarogya Setu mobile app. 2020. Available from: https://www.mygov.in/aarogya-setu-app/ [Accessed 3rd February 2021].

[129]DP-3T/documents: decentralized privacy-preserving proximity tracing-documents. The DP-3T Project. Available from: https://github.com/DP-3T/documents [Accessed 31st January 2021].

[130]PEPP-PT. High-level pverview: pan-European privacy-preserving proximity tracing. Available from: https://github. com/pepp-pt/pepp-pt-documentation/blob/master/PEPP-PT-high-leveloverview.pdf [Accessed 2nd February 2021].

[131]Apple. Apple and Google partner on COVID-19 contact tracing technology. 2020. Available from: https://www. apple.com/newsroom/2020/04/appleand-google-partner-on-covid-19contact-tracing-technology/ [Accessed 3rd February 2021].

[132]Jia JS, Lu X, Yuan Y, Xu G, Jia J, Christakis NA. Population flow drives spatio-temporal distribution of COVID-19 in China. Nature. 2020; 582(7812): 389-405. Available from: doi: 10.1038/s41586-020-2284-y.

[133]Chinazzi M, Davis JT, Ajelli M, Gioannini C, Litvinova M, Merler S, et al. The effect of travel restrictions on the spread of the 2019 novel coronavirus (COVID-19) outbreak. Science. 2020; 368(6489): 395-400. Available from: doi: 10.1126/science.aba9757.

[134]Kraemer MUG, Yang CH, Gutierrez B, Wu CH, Klein B, Pigott DM, et al. The effect of human mobility and control measures on the COVID-19 epidemic in China. Science. 2020; 368(6490): 493-497. Available from: doi: 10.1126/science.abb4218.

[135]China Data Lab. Baidu mobility data. Harvard Dataverse. 2020. Available from: https://oi.org/10.7910/DVN/ FAEZIO [Accessed 3rd February 2021].

[136]Google. COVID-19 Community Mobility Reports. Available from: https://www.google.com/covid19/mobility/ [Accessed 2nd February 2021].

[137]Apple. COVID-19-Mobility Trends Reports. Available from: https://www.apple.com/covid19/mobility [Accessed 3rd February 2021].

[138]World Health Organization (WHO). Coronavirus Disease (COVID-19) Situation Reports. Report number: 13, 2020. Available from: https://www.who.int/docs/default-source/coronaviruse/situation-reports/20200202-sitrep-13ncov-v3.pdf?sfvrsn=195f4010_6 [Accessed 3rd February 2021].

[139]Raamkumar AS, Tan SG, Wee HL. Measuring the outreach efforts of public health authorities and the public response on Facebook during the COVID-19 pandemic in early 2020: Cross-country comparison. Journal of Medical Internet Research. 2020; 22(5): 1-12. Available from: doi: 10.2196/19334.

[140]Google. SOS alerts help. Available from: https://support.google.com/sosalerts/?hl=en [Accessed 2nd February $2021]$.

[141]WhatsApp. How WhatsApp can help you stay connected during the coronavirus (COVID-19) pandemic. 2020. Available from: https:/www.whatsapp.com/coronavirus [Accessed 2nd February 2021].

[142]Greenhalgh T, Koh GCH, Car J. Covid-19: A remote assessment in primary care. British Medical Journal. 2020; 368: 1-5. Available from: doi: 10.1136/bmj.m1182.

[143]Shi F, Wang J, Shi J, Wu Z, Wang Q, Tang Z, et al. Review of artificial intelligence techniques in imaging data acquisition, segmentation and diagnosis for COVID-19. IEEE Reviews in Biomedical Engineering. 2020; $14:$ 4-15. Available from: doi: 10.1109/rbme.2020.2987975.

[144]Martin A, Nateqi J, Gruarin S, Munsch N, Abdarahmane I, Zobel M, et al. An artificial intelligence-based first-line defence against COVID-19: Digitally screening citizens for risks via a chatbot. Scientific Reports. 2020; $10(1)$ : 1-7. Available from: doi: 10.1038/s41598-020-75912-X.

[145]Wang Y, Lu X, Zhang Y, Zhang X, Wang K, Liu J, et al. Precise pulmonary scanning and reducing medical radiation exposure by developing a clinically applicable intelligent $\mathrm{CT}$ system: Toward improving patient care. EBioMedicine. 2020; 54: 1-10. Available from: doi: 10.1016/j.ebiom.2020.102724.

[146]Forbes. Morgan, B. 10 Examples of healthcare innovation in the face of COVID. 2021. Available from: https:// www.forbes.com/sites/blakemorgan/2021/02/01/10-examples-of-healthcare-innovation-in-the-face-ofcovid/?sh=2a062195680d [Accessed 5th February 2021]. 
[147]Tavakol S, Zahmatkeshan M, Mohammadinejad R, Mehrzadi S, Joghataei MT, Alavijeh MS, et al. The role of nanotechnology in current COVID-19 outbreak. Heliyon. 2021; 7(4): e06841. Available from: doi: 10.1016/ j.heliyon.2021.e06841.

[148]Qui M, Sing A, Wang D, Qu J, Swihart M, Zhang H, et al. Biocompatible and biodegradable inorganic nanostructures for nanomedicine: Silicon and black phosphorus. Nano Today. 2019; 25: 135-155. Available from: doi: 10.1016/j.nantod.2019.02.012.

[149]Xie Z, Fan T, An J , Choi W, Duo Y, Ge Y, et al. Emerging combination strategies with phototherapy in cancer nanomedicine. Chemical Society Reviews. 2020; 49(22): 8065-8087.Available from: doi: 10.1039/d0cs00215a.

[150]Luo M, Fan T, Zhou Y, Zhang H, Mei L. 2D black phosphorus-based biomedical applications. Advanced Functional Materials. 2019; 29(13): 1808306. Available from: doi: 10.1002/adfm.201808306.

[151]Chen J, Fan T, Xie Z, Zeng Q, Xue P, Zheng T, et al. Advances in nanomaterials for photodynamic therapy applications: Status and challenges. Biomaterials. 2020; 237: 119827. Available from: doi: 10.1016/ j.biomaterials.2020.119827.

[152]Tang Z, Kong N, Ouyang J, Feng C, Kim NY, Ji X, et al. Phosphorus science-Oriented design and synthesis of multifunctional nanomaterials for biomedical applications. Matter. 2020; 2(2): 297-322. Available from: doi: 10.1016/j.matt.2019.12.007.

[153]Formlabs. 3D-printed test swabs for COVID-19 testing. 2020. Available from: https://formlabs.com/asia/covid-19response/covid-test-swabs/ [Accessed 25th January 2021].

[154]Hong Y, Huh YM, Yoon DS, Yang J. Nanobiosensors based on localized surface plasmon resonance for biomarker detection. Journal of Nanomaterials. 2012; 2012: 1-14. Available from: doi: 10.1155/2012/759830.

[155]Chakhalian D, Shultz RB, Miles CE, Kohn J. Opportunities for biomaterials to address the challenges of COVID-19. Journal of Biomedical Materials Research. 2020; 108(10): 1974-1990. Available from: doi: 10.1002/ jbm.a.37059.

[156]Pardee K, Green AA, Takahashi MK, Braff D, Lambert G, Lee JW, et al. Rapid, low-cost detection of zika virus using programmable biomolecular components. Cell. 2016; 165(5): 1255-1266. Available from: doi: 10.1016/ j.cell.2016.04.059.

[157]Qui G, Gai Z, Tao Y, Schmitt J, Ublick GAK, Wang J. Dual-functional plasmonic photothermal biosensors for highly accurate severe acute respiratory syndrome coronavirus 2 detection. ACS Nano. 2020; 14(5): 5268-5277. Available from: doi: 10.1021/acsnano.0c02439.

[158]Xiang J, Yan M, Li H, Lui T, Lin C, Huang S, et al. Evaluation of enzyme-linked immunoassay and colloidal gold-immunochromatographic assay kit for detection of novel coronavirus (SARS-Cov-2) causing an outbreak of pneumonia (COVID-19). medRxiv. 2020; 1-13. Available from: https://doi.org/10.1101/2020.02.27.20028787 [Accessed 27th January 2021].

[159]Calucho E, Parolo C, Rivas L, Diduk RA, Merkoci A. Chapter Ten-Nanoparticle-based lateral flow assays. Comprehensive Analytical Chemistry. 2020; 89: 317. Available from: doi: 10.1016/bs.coac.2020.04.011.

[160]Ang GY, Yu CY, Yean CY. Ambient temperature detection of PCR amplicons with a novel sequence-specific nucleic acid lateral flow biosensor. Biosensors and Bioelectronics. 2012; 38(1): 151-156. Available from: doi: 10.1016/j.bios.2012.05.019.

[161]Mirkin CA, Letsinger RL, Mucic RC, Storhoff JJ. A DNA-based method for rationally assembling nanoparticles into macroscopic materials. Nature. 1996; 382(6592): 607-609. Available from: doi: 10.1038/382607a0.

[162]Liu J, Lu Y. Preparation of aptamer-linked gold nanoparticle purple aggregates for colorimetric sensing of analytes. Nature Protocols. 2006; 1(1): 246-252. Available from: doi: 10.1038/nprot.2006.38.

[163]Koets M, Sander I, Bogdanovic J, Doekes G, Amerongen AV. A rapid lateral flow immunoassay for the detection of fungal alpha-amylase at the workplace. Journal of Environmental Monitoring. 2006; 8(9): 942-946. Available from: doi: 10.1039/b605389k.

[164]Qiu W, Xu H, Takalkar S, Gurung AS, Liu B, Zheng Y, et al. Carbon nanotube-based lateral flow biosensor for sensitive and rapid detection of DNA sequence. Biosensors and Bioelectronics. 2015; 64: 367-372. Available from: doi: 10.1016/j.bios.2014.09.028.

[165]Zamora-Galvez A, Morales-Narvaez EM, Romero J, Merkoci A. Photoluminescent lateral flow based on nonradiative energy transfer for protein detection in human serum. Biosensors and Bioelectronics. 2018; 100: $208-213$. Available from: doi: 10.1016/j.bios.2017.09.013.

[166]Bruno JG. Application of DNA aptamers and quantum dots to lateral flow test strips for detection of foodborne pathogens with improved sensitivity versus colloidal gold. Pathogens. 2014; 3(2): 341-355. Available from: doi: 10.3390/pathogens3020341. 
[167]You M, Lin M, Gong Y, Wang S, Li A, Ji L, et al. Household fluorescent lateral flow strip platform for sensitive and quantitative prognosis of heart failure using dual-color upconversion nanoparticles. ACS Nano. 2017; 11(6): 62616270. Available from: doi: 10.1021/acsnano.7b02466.

[168]Corstjens P, Zuiderwijk M, Brink A, Li S, Feindt H, Niedbala RS, et al. Use of up-converting phosphor reporters in lateral-flow assays to detect specific nucleic acid sequences: a rapid, sensitive DNA test to identify human papillomavirus type 16 infection. Clinical Chemistry. 2001; 47(10): 1885-1893.

[169]Edwards KA, Baeumner AJ. Liposome-enhanced lateral-flow assays for the sandwich-hybridization detection of RNA. Methods in Molecular Biology. 2009; 504: 185-215. Available from: doi: 10.1007/978-1-60327-569-9_13.

[170]Edwards KA, Baeumner AJ. Optimization of DNA-tagged dye-encapsulating liposomes for lateral-flow assays based on sandwich hybridization. Analytical and Bioanalytical Chemistry. 2006; 386(5): 1335-1343. Available from: doi: 10.1007/s00216-006-0705-X.

[171]Wang DB, Tian B, Zhang ZP, Wang XY, Fleming J, Bi LJ, et al. Detection of bacillus anthracis spores by superparamagnetic lateral-flow immunoassays based on "Road Closure". Biosensors and Bioelectronics. 2015; 67: 608614. Available from: doi: 10.1016/j.bios.2014.09.067.

[172]Zare M, Sillanpaa M, Ramakrishna S. Essential role of quantum science and nanoscience in antiviral strategies; COVID-19. Materials Advances. 2021; 2(7): 2188-2199. Available from: doi: 10.1039/D1MA00060H.

[173]Rabiee N, Bagherzadeh M, Ghasemi A, Zare H, Ahmadi S, Fatahi Y, et al. Point-of-use rapid detection of SARSCoV-2: Nanotechnology-enabled solutions for the COVID-19 pandemic. International Journal of Molecular Sciences. 2020; 21(14): 1-24. Available from: doi: 10.3390/ijms21145126.

[174]Guo P, We C. Quantum dots for robust and simple assays using single particles in nanodevices. Nanomedicine: Nanotechnology, Biology and Medicine. 2005; 1(2): 122-124. Available from: doi: 10.1016/j.nano.2005.04.004.

[175]Yeh HC, Ho YP, Wang TH. Quantum dot-mediated biosensing assays for specific nucleic acid detection. Nanomedicine: Nanotechnology, Biology and Medicine. 2005; 1(2): 115-121. Available from: doi: 10.1016/ j.nano.2005.03.004.

[176]Cao YWC, Jin R, Mirkin CA. Nanoparticles with Raman spectroscopic fingerprints for DNA and RNA detection. Science. 2002; 297(5586): 1536-1540. Available from: doi: 10.1126/science.297.5586.1536.

[177]Medintz IL, Clapp AR, Mattoussi H, Goldman ER, Fisher B, Mauro JM. Self-assembled nanoscale biosensors based on quantum dot FRET donors. Nature Materials. 2003; 2(9): 630-638. Available from: doi: 10.1038/ nmat961.

[178]Taton TA, Mirkin CA, Letsinger RL. Scanometric DNA array detection with nanoparticle probes. Science. 2000; 289(5485): 1757-1760.

[179]Pemmada R, Zhu X, Dash M, Zhou Y, Ramakrishna S, Peng X, et al. Science-based strategies of antiviral coatings with viricidal properties for the COVID-19 like pandemics. Materials. 2020; 13(18): 4041. Available from: doi: 10.3390/ma13184041.

[180]Vigneswari S, Amelia TSM, Hazwan MH, Mouriya GK, Bhubalan K, Amirul AAA, et al. Transformation of biowaste for medical applications: Incorporation of biologically derived silver nanoparticles as antimicrobial coating. Antibiotics. 2021; 10(3): 229. Available from: doi: 10.3390/antibiotics10030229.

[181]Lara HH, NuNez NVA, Turrent LI, Padilla CR. Mode of antiviral action of silver nanoparticles against HIV-1. Journal of Nanobiotechnology. 2010; 8(1): 1-10. Available from: doi: 10.1186/1477-3155-8-1.

[182]Ishida T. Antiviral activities if $\mathrm{Cu}^{2+}$ ions in viral prevention, replication, RNA degradation, and for antiviral efficacies of lytic virus, ROS-mediated virus, copper chelation. World Scientific News. 2018; 99: 148-168. Available from: http://psjd.icm.edu.pl/psjd/element/bwmeta1.element.psjd-47e07c40-4cfb-46a6-a1e8-e9115e342ce6 [Accessed 27th January 2021].

[183]Gurunathan S, Qasim M, Choi Y, Do JT, Park C, Hong K, et al. Antiviral potential of nanoparticles-can nanoparticles fight against coronaviruses? Nanomaterials. 2020; 10(9): 1645. Available from: doi: 10.3390/ nano10091645.

[184]Zhang XF, Liu ZG, Shen W, Gurunathan S. Silver nanoparticles: Synthesis, characterization, properties, applications, and therapeutic approaches. International Journal of Molecular Sciences. 2016; 17(9): 1534. Available from: doi: 10.3390/ijms17091534.

[185]Gupta A, Moyano DF, Parnsubsakul A, Papadopoulos A, Wang L-S, et al. Ultrastable and biofunctionalizable gold nanoparticles. ACS Applied Materials \& Interfaces. 2016; 8(22): 14096-14101. Available from: doi: 10.1021/ acsami.6b02548.

[186]Michalet X, Pinaud FF, Bentolila LA, Tsay JM, Doose S, Li JJ, et al. Quantum dots for live cells, in vivo imaging, and diagnostics. Science. 2005; 307(5709): 538-544. Available from: doi: 10.1126/science.1104274. 
[187]Ghosal K, Sarkar K. Biomedical applications of graphene nanomaterials and beyond. ACS Biomaterial Science and Engineering. 2018; 4(8): 2653-2703. Available from: doi: 10.1021/acsbiomaterials.8b00376.

[188]Antoine TE, Mishra YK, Trigilio J, Tiwari V, Adelung R, Shukla D. Prophylactic, therapeutic and neutralizing effects of zinc oxide tetrapod structures against herpes simplex virus type-2 infection. Antiviral Research. 2012; 96(3): 363-375. Available from: doi: 10.1016/j.antiviral.2012.09.020.

[189]Bender AR, von Briesen H, Kreuter J, Duncan IB, Rübsamen-Waigmann H. Efficiency of nanoparticles as a carrier system for antiviral agents in human immunodeficiency virus-infected human monocytes/macrophages in vitro. Antimicrobial Agents and Chemotherapy. 1996; 40(6): 1467-1471. Available from: doi: 10.1128/AAC.40.6.1467.

[190]Vollenbroich D, Zel MO, Vater J, Kamp RM, Pauli G. Mechanism of inactivation of enveloped viruses by the biosurfactant surfactin from bacillus subtilis. Biologicals. 1997; 25(3): 289-297. Available from: doi: 10.1006/ biol.1997.0099.

[191]Tiliket G, Sage DL, Moules V, Calatrava MR, Lina B, Valleton JM, et al. A new material for airborne virus filtration. Chemical Engineering Journal. 2011; 173(2): 341-351. Available from: doi: 10.1016/j.cej.2011.07.059.

[192]Hyun J, Lee SG, Hwang J. Application of corona discharge-generated air ions for filtration of aerosolized virus and inactivation of filtered Virus. Journal of Aerosol Science. 2017; 107: 31-40. Available from: doi: 10.1016/ j.jaerosci.2017.02.004.

[193] Sheihet L, Garbuzenko OB, Bushman J, Gounder MK, Minko T, Kohn J. Paclitaxel in tyrosine-derived nanospheres as a potential anti-cancer agent: In vivo evaluation of toxicity and efficacy in comparison with paclitaxel in cremophor. European Journal of Pharmaceutical Sciences. 2012; 45(3): 320-329. Available from: doi: 10.1016/ j.ejps.2011.11.017.

[194]Rothan HA, Stone S, Natekar J, Kumari P, Arora K, Kumar M. The FDA-approved gold drug auranofin inhibits novel coronavirus (SARS-COV-2) replication and attenuates inflammation in human cells. Virology. 2020; 547: 7-11. Available from: doi: 10.1016/j.virol.2020.05.002.

[195]Tang Z, Zhang X, Shu Y, Guo M, Zhang H, Tao W. Insights from nanotechnology in COVID-19 treatment. Nano Today. 2021; 36: 101019. Available from: doi: 10.1016/j.nantod.2020.101019.

[196]Tavakol S, Seifalian AM. Vitamin E at a high dose as an anti-ferroptosis drug and not just a supplement for COVID-19 treatment. Biotechnology and Applied Biochemistry. 2021. Available from: doi: 10.1002/bab.2176.

[197]Kim E, Erdos G, Huang S, Kenniston TW, Balmert SC, Carey CD, et al. Microneedle array delivered recombinant coronavirus vaccines: Immunogenicity and rapid translational development. EBioMedicine. 2020; 55: 1-12. Available from: https://doi.org/10.1016/j.ebiom.2020.102743 [Accessed 27th January 2021].

[198]Kim J, Koo BK, Knoblich JA. Human organoids: model systems for human biology and medicine. Nature Reviews: Molecular Cell Biology. 2020; 21(10): 571-584. Available from: doi: 10.1038/s41580-020-0259-3.

[199]Clevers H. COVID-19: Organoids go viral. Nature Reviews: Molecular Cell Biology. 2020; 21(7): $355-356$. Available from: doi: 10.1038/s41580-020-0258-4.

[200]Plat DJ, Miner JJ. Consequences of congenital Zika virus infection. Current Opinion in Virology. $2017 ; 27: 1-7$. Available from: doi: 10.1016/j.coviro.2017.09.005.

[201]Youk J, Kim T, Evans KV, Jeong Y, Hu Y, Hong SP, et al. Three-dimensional human alveolar stem cell culture models reveal infection response to SARS-CoV-2. Cell Stem Cell. 2020; 27(6): 905-919. Available from: doi: 10.1016/j.stem.2020.10.004.

[202]Zhou J, Li C, Liu X, Chiu MC, Zhao X, Wang D, et al. Infection of bat and human intestinal organoids by SARSCoV-2. Nature Medicine. 2020; 26(7): 1077-1083. Available from: doi: 10.1038/s41591-020-0912-6.

[203]Zhang M, Wang P, Luo R, Wang Y, Li Z, Guo Y, et al. Biomimetic human disease model of SARS-CoV-2-induced lung injury and immune responses on organ chip system. Advanced Science. 2020; 8(3): 2002928. Available from: doi: 10.1002/advs.202002928.

[204]Centers for Disease Control and Prevention (CDC). COVID-19, Emerging SARS-CoV-2 Variants. Available from: https://www.cdc.gov/coronavirus/2019-ncov/more/science-and-research/scientific-brief-emerging-variants.html [Accessed 3rd February 2021].

[205]Centers for Disease Control and Prevention (CDC). COVID-19, About variants of the virus that causes COVID-19. Available from: https://www.cdc.gov/coronavirus/2019-ncov/variants/variant.html. [Accessed 21st June 2021].

[206]World Health Organization (WHO). Tracking SARS-CoV-2 variants. Available from: https:/www.who.int/en/ activities/tracking-SARS-CoV-2-variants/ [Accessed 21st June 2021].

[207]Mayo Clinic. COVID-19 variants: What's the concern? Available from: https://www.mayoclinic.org/diseasesconditions/coronavirus/expert-answers/covid-variant/faq-20505779 [Accessed 21st June 2021].

[208]Global Virus Network (GVN). Epsilon (B.1.427/B.1.429). Available from: https://gvn.org/covid-19/epsilon-b-1- 
427-b-1-429/ [Accessed 21st June 2021].

[209]Wikipedia. SARS-CoV-2 delta variant. Available from: https://en.wikipedia.org/wiki/SARS-CoV-2_Delta_variant. [Accessed 21st June 2021].

[210]Emary KRW, Golubchik T, Aley PK, Ariani CV, Angus B, Bibi S, et al. Efficacy of ChAdOx1 nCoV-19 (AZD1222) vaccine against SARS-CoV-2 variant of concern 202012/01 (B.1.1.7): An exploratory analysis of a randomised controlled trial. Lancet. 2021; 397(10282): 1351-1362. Available from: doi: 10.1016/S0140-6736(21)00628-0.

[211]Mahase E. Covid-19: Novavax vaccine efficacy is $86 \%$ against UK variant and 60\% against South African variant. British Medical Journal. 2021; 372: n296. Available from: doi: 10.1136/bmj.n296.

[212]Wang P, Nair MS, Liu L, Iketani S, Luo Y, Guo Y, et al. Antibody resistance of SARS-CoV-2 variants B.1.351 and B.1.1.7. Nature. 2021; 593(7857): 130-135. Available from: doi: 10.1038/s41586-021-03398-2.

[213]Hoffmann M, Arora P, Groß R, Seidel A, Hörnich BF, Hahn AS, et al. SARS-CoV-2 variants B.1.351 and P.1 escape from neutralizing antibodies. Cell. 2021; 184(9): 2384-2393 Available from: doi: 10.1016/j.cell.2021.03.036.

[214]Wilder-Smith A, Chiew C, Lee VJ. Can we contain the COVID-19 outbreak with the same measures as for SARS? Lancet Infectious Diseases. 2020; 20(5): 102-107. Available from: doi: 10.1016/S1473-3099(20)30129-8.

[215]Marcel S, Christian AL, Richard N, Silvia S, Emma H, Jacques F, et al. COVID-19 epidemic in Switzerland: On the importance of testing, contact tracing and isolation. Swiss Medical Weekly. 2020; 150: w20225. Available from: doi: 10.4414/smw.2020.20225.

[216]Shi P, Dong Y, Yan H, Li X, Zhao C, Liu W, et al. The impact of temperature and absolute humidity on the coronavirus disease 2019 (COVID-19) outbreak-evidence from China. medRxiv. 2020; 1-27. Available from: https://doi.org/10.1101/2020.03.22.20038919 [Accessed 4th February 2021].

[217]Khanna RC, Cicinelli MV, Gilbert SS, Honavar SG, Murthy GVS. COVID-19 pandemic: Lessons learned and future directions. Indian Journal of Ophthalmology. 2020; 68(5): 703-710. Available from: doi: 10.4103/ijo. IJO_843_20. 